Published in final edited form as:

Nat Immunol. 2021 April ; 22(4): 520-529. doi:10.1038/s41590-021-00895-4.

\title{
Blockade of IL-22 signaling reverses erythroid dysfunction in stress-induced anemias
}

\author{
Mahesh Raundhal ${ }^{1,2,3,}{ }^{,}$, Shrestha Ghosh ${ }^{1,2,3}$, Samuel A. Myers ${ }^{4}$, Michael S. Cuoco ${ }^{5}$, \\ Meromit Singer $^{2,4,6}$, Steven A. Carr ${ }^{4}$, Sushrut S. Waikar ${ }^{7,8}$, Joseph V. Bonventre ${ }^{7}$, Jerome \\ Ritz $^{9}$, Richard M. Stone ${ }^{9}$, David P. Steensma ${ }^{9}$, Aviv Regev ${ }^{5,10,11}$, Laurie H. Glimcher ${ }^{1,2,3,{ }^{*}}$ \\ ${ }_{1}^{1}$ Department of Cancer Immunology and Virology, Dana-Farber Cancer Institute, Boston, MA \\ 02215, USA. \\ 2Department of Immunology, Harvard Medical School, Boston, MA, 02215, USA. \\ ${ }^{3}$ Department of Medicine, Brigham and Women's Hospital, Boston, MA 02215, USA. \\ ${ }^{4}$ Broad Institute of MIT and Harvard, Cambridge, MA 02142, USA. \\ ${ }^{5}$ Klarman Cell Observatory, Broad Institute of Harvard and MIT, Cambridge, MA, USA. \\ ${ }^{6}$ Department of Data Sciences, Dana-Farber Cancer Institute, Boston, MA, USA.
}

\footnotetext{
Users may view, print, copy, and download text and data-mine the content in such documents, for the purposes of academic research, subject always to the full Conditions of use:http://www.nature.com/authors/editorial_policies/license.html\#terms

"Corresponding authors: Laurie H. Glimcher, M.D., President and CEO, Dana-Farber Cancer Institute, Richard and Susan Smith Professor of Medicine, Harvard Medical School, 450 Brookline Avenue, Dana 1628, Boston, MA 02215,

Laurie_Glimcher@dfci.harvard.edu; Mahesh Raundhal, Ph.D., Dana-Farber Cancer Institute, SM746, 1 Jimmy Fund Way, Boston, MA 02215, Mahesh_Raundhal@dfci.harvard.edu.

Author Contributions

M.R. and L.H.G conceived the study, designed experiments, analyzed the data and wrote the manuscript; M.R. performed the experiments; S.G. assisted with in vitro experiments, S.A.M. performed proteomic profiling and data analysis, M.S.C. performed RNA-Seq, M.S. processed RNA-Seq data, S.A.C. analyzed proteomic profiling data, S.S.W. and J.V.B. collected CKD patient samples and related clinical information and analyzed the data, J.R., R.M.S, and D.P.S. collected MDS patient samples and related clinical information and analyzed the data. A.R. supervised RNA-Seq experiment and analyzed data.

Competing Interests statement

An invention disclosure has been filed based on the data generated in this study.

From August 4th, 2020, Meromit Singer is an employee of Guardant Health.

S.S.W. has served on the steering committee of GSK trial on an oral hypoxia-inducible factor prolyl hydroxylase inhibitor, as a potential treatment for anemia associated with chronic kidney disease; S.S.W. has also received consulting fees from Public Health Advocacy Institute, CVS, Roth Capital Partners, Kantum Pharma, Mallinckrodt, Wolters Kluewer, GE Health Care, Allena Pharmaceuticals, Mass Medical International, JNJ, Venbio, Strataka, Takeda, Cerus, and Pfizer. D.P.S. has served on independent data safety monitoring committees for clinical trials supported by Takeda, Astex, Janssen and Onconova; has consulted for Celgene and Daiichi Sankyo; and has received research support (to the institution) for clinical trials sponsored by Aprea, H3 Biosciences, Syros and Astra Zeneca. J.R. reports research funding from Amgen, Equillium, and Kite Pharma; and consulting income from Aleta Biotherapeutics, Avrobio, Celgene, Falcon Therapeutics, LifeVault Bio, Rheos Medicines, Talaris Therapeutics and TScan Therapeutics.

R.M.S. has served on independent data safety monitoring committees for trials supported by Celgene, Takeda and Argenix; has consulted for AbbVie, Actinium, Agios, Amgen, Arog, Astellas, AstraZeneca, Biolinerx, Celgene, Daiichi Sankyo, Fujifilm, Janssen, Juno, Macrogenics, Novartis, Ono, Orsenix, Pfizer, Roche, Stemline, Sumitomo, Takeda, and Trovagene; and has received research support (to the institution) for clinical trials sponsored by AbbVie, Agios, Arog, and Novartis. S.A.C. is a member of the scientific advisory boards of Kymera, PTM BioLabs and Seer and a scientific advisor to Pfizer and Biogen.

A.R. is a SAB member of ThermoFisher Scientific, Neogene Therapeutics, Asimov and Syros Pharmaceuticals. A.R. is a cofounder of and equity holder in Celsius Therapeutics and an equity holder in Immunitas. From August 1, 2020, AR is an employee of Genentech. L.H.G. is a former Director of Bristol-Myers Squibb and the Waters Corporation and is currently on the board of directors of and holds equity in GlaxoSmithKline Pharmaceuticals and Analog Devices, Inc. She also serves on the scientific advisory boards of Repare Therapeutics, Abpro Therapeutics and Kaleido Therapeutics. All other authors declare no relevant competing interest.
} 
${ }^{7}$ Renal Division, Department of Medicine, Brigham and Women's Hospital, Harvard Medical School, Boston, MA 02115, USA.

${ }^{8}$ Renal Section, Boston University Medical Center, Boston, MA 02118, USA.

${ }^{9}$ Department of Medical Oncology, Dana-Farber Cancer Institute, Harvard Medical School, Boston, MA 02215, USA.

${ }^{10}$ Howard Hughes Medical Institute, Chevy Chase, MD, USA.

${ }^{11}$ Koch Institute for Integrative Cancer Research, Department of Biology, Massachusetts Institute of Technology, Cambridge, MA, USA.

\section{Abstract}

Patients with myelodysplastic syndromes (MDS) display severe anemia but the mechanisms underlying this phenotype are incompletely understood. Right open-reading-frame kinase 2 (RIOK2) encodes a protein kinase located at $5 \mathrm{q} 15$, a region frequently lost in $\operatorname{MDS} \operatorname{del}(5 \mathrm{q})$ patients. Here, we show that hematopoietic cell-specific haploinsufficient deletion of Riok2 ( $R i o k 2^{f /+} \operatorname{Vav}^{\text {cre }}$ ) led to reduced erythroid precursor frequency leading to anemia. Proteomic analysis of $\operatorname{Riok}^{\mathrm{f} /+} \operatorname{Vav}{ }^{\text {cre }}$ erythroid precursors suggested immune system activation and transcriptomic analysis revealed an increase in p53-dependent interleukin-22 (IL-22) in Riok $2^{\mathrm{f} /+} \operatorname{Vav}_{1} 1^{\text {cre }} \mathrm{CD}^{+}{ }^{+} \mathrm{T}$ cells $\left(\mathrm{T}_{\mathrm{H}} 22\right)$. Further, we discovered that the IL-22 receptor, IL-22RA1, was unexpectedly present on erythroid precursors. Blockade of IL-22 signaling alleviated anemia not only in Riok $2^{\mathrm{f} /+} \operatorname{Vav}^{\mathrm{cre}}$ mice but also in wild-type mice. Serum concentrations of IL-22 were increased in the subset of del(5q) MDS patients as well as patients with anemia secondary to chronic kidney disease (CKD). This work reveals a possible therapeutic opportunity for reversing many stress-induced anemias by targeting IL-22 signaling.

\section{Keywords}

IL-22; del(5q) MDS; anemia; myeloproliferation; Riok2; p53

\section{Introduction}

Myelodysplastic syndromes (MDS) are a group of cancers characterized by failure of blood cells in the bone marrow to mature. About 7 out of 100,000 people are affected and the typical survival time following diagnosis is less than three years. While a sizable percentage of MDS cases progress to acute myelogenous leukemia (AML), most of the morbidity and mortality associated with MDS results not from transformation to AML but rather from hematological cytopenias.

Anemia is the most common hematologic manifestation of MDS, particularly in the subset of patients with del(5q) MDS. Del(5q), either isolated or accompanied by additional cytogenetic abnormalities, is the most commonly detected chromosomal abnormality in MDS, reported in $10-15 \%$ of patients ${ }^{1-4}$. The severe anemia in del(5q) MDS patients has been linked to haploinsufficiency of ribosomal proteins such as RPS14 and RPS195; 6 . Previous studies using mice with haploinsufficient $5 q$ gene deletions revealed diminished 
erythroid progenitor frequency ${ }^{7-10}$ but the mechanisms underlying this phenotype are incompletely understood. Right open-reading-frame kinase 2 (RIOK2) encodes an atypical serine-threonine protein kinase with an indispensable function as a component of the pre-40S ribosome subunit ${ }^{16}$.

There is growing evidence for the role of activated innate immunity and inflammation as well as immune dysregulation in the pathogenesis of MDS $^{17-20}$. Abnormal expression of numerous cytokines has been reported in MDS $^{21-24}$. Chronic immune stimulation in both hematopoietic stem and progenitor cells (HSPCs) and the bone marrow (BM) microenvironment ${ }^{25}$ was suggested to be central to the pathogenesis of MDS. In patients with chronic inflammation, cytokines in the BM have been associated with inhibition of erythropoiesis ${ }^{26}$. Despite growing evidence for a link between the immune system and MDS pathogenesis, no study has identified the mechanism by which the immune microenvironment may initiate or contribute to the MDS phenotype. Further it remains unclear how ribosomal protein haploinsufficiency is connected with the immune system in MDS.

\section{Results}

\section{Riok2 haploinsufficiency leads to anemia}

We previously noted that Riok 2 expression was reduced in $\mathrm{T}$ cells lacking the endoplasmic reticulum stress transcription factor Xbp $1^{27}$. RIOK2 is a little-studied atypical serinethreonine protein kinase ${ }^{11}$ encoded by RIOK2 at $5 \mathrm{q} 15$ in the human genome (Extended Data Fig. 1a), adjacent to the $5 q$ commonly deleted regions in MDS and frequently lost in MDS and acute myeloid leukemia ${ }^{12-15}$.Gene expression commons (GEXC) ${ }^{28}$ analysis revealed that in mouse BM, Riok2 expression is highest in primitive colony-forming-unit erythroid (pCFU-E) cells, suggesting that RIOK2 may be involved in maintaining red blood cell (RBC) output (Extended Data Fig. 1d). To further study the role of RIOK2 in hematopoiesis, we generated Vav1-Cre transgenic floxed Riok2 (Riok2 $\left.2^{\mathrm{f} /+} \operatorname{Vav}^{1 \mathrm{cre}}\right)$ mice in which the Cre recombinase is under the control of the hematopoietic cell-specific Vav1 promoter. Riok2 floxed mice were generated with exons 5 and 6 flanked by $l_{0 x} P$ sites (Extended Data Fig. 1b, c). Interestingly, no Vav1-Cre floxed Riok2 homozygous-deficient mice ( $R$ iok $2^{\mathrm{f} / \mathrm{f}} \operatorname{Vav}^{\mathrm{cre}}$ ) were recovered (Extended Data Fig. 1f), indicating embryonic lethality from complete hematopoietic deletion of Riok2. However, heterozygous Riok $2^{f /+} \operatorname{Vav} 1^{\text {cre }}$ mice were viable with approximately 50\% Riok 2 mRNA expression in hematopoietic cells compared to that of $\operatorname{Vav}^{\mathrm{Cre}}$ controls (Extended Data Fig. 1e). As seen with other ribosomal protein haploinsufficiency mouse models ${ }^{10}, \mathrm{BM}$ cells from Riok $2^{\mathrm{f} /+} \operatorname{Vav}{ }^{\mathrm{cre}}$ mice showed reduced nascent protein synthesis in vivo compared to $\mathrm{Vav}_{1}{ }^{\mathrm{Cre}}$ controls (Extended Data Fig. $1 \mathrm{~g}$ ), consistent with a RIOK2 role in maturation of the pre- 40 S ribosome. A recent study 29 showed that ribosomal protein deficiency-mediated reduced protein synthesis predominantly affects erythropoiesis over myelopoiesis.

Consistent with the high expression of Riok 2 in pCFU-e cells in the BM, aged ( $>60 \mathrm{wks})$ mice with heterozygous deletion of Riok 2 in hematopoietic cells (Riok $\left.2^{\mathrm{fl+}} \operatorname{Vav} 1^{\mathrm{cre}}\right)$ displayed anemia with reduced peripheral blood (PB) RBC numbers, hemoglobin (Hb), and hematocrit (HCT) (Fig. 1a). We next determined whether Riok2 haploinsufficiency-mediated 
anemia was secondary to a defect in erythroid development in the BM, the major site of erythropoiesis. We characterized the stages (referred to here as RI, RII, RIII and RIV) of erythropoiesis by flow cytometry using the expression of Ter119 and CD71 (Extended Data Fig. 2a). Riok $2^{\mathrm{f} /+} \operatorname{Vav}{ }^{\mathrm{cre}}$ mice had impaired erythropoiesis in the BM (Fig. 1b, Extended Data Fig. 2b). Moreover, Riok2 haploinsufficiency led to increased apoptosis in erythroid precursors compared to controls (Fig. 1c). Additionally, Riok $2^{\mathrm{f} /+} \operatorname{Vav}^{\text {cre }}$ erythroid precursors showed a decrease in cell quiescence with cell cycle block at the G1 phase (Extended Data Fig. 2c). A block in cell cycle is driven by a group of proteins known as cyclin-dependent kinase inhibitors (CKI). The expression of p21 (a CKI encoded by Cdkn1a) was increased in erythroid precursors from Riok $2^{\mathrm{f} /+}$ Vav $1^{\text {cre }}$ mice compared to Riok $2^{+/+}$Vav ${ }^{\text {cre }}$ controls (Extended Data Fig. 2d).

We next examined the effect of Riok 2 haploinsufficiency on stress-induced erythropoiesis using 8-12 wk old mice in which hemolysis was induced by non-lethal phenylhydrazine treatment $(25 \mathrm{mg} / \mathrm{kg}$ on days 0 and 1$)$. After acute hemolytic stress, Riok $2^{\mathrm{f} /+} \operatorname{Vav}^{\mathrm{cre}}$ mice developed more severe anemia and had a delayed RBC recovery response, as compared to Riok $2^{+/+} \operatorname{Vav}^{\text {cre }}$ control mice (Fig. 1d) and succumbed faster to a lethal dose of phenylhydrazine $\left(35 \mathrm{mg} / \mathrm{kg}\right.$ on days 0 and 1) compared to $\operatorname{Vav}^{1}{ }^{\text {cre }}$ controls (Extended Data Fig. 2e). The anemia in young phenylhydrazine-administered $R i o k 2^{\mathrm{f} /+}$ Vav $1^{\text {cre }}$ mice seen on day 7 was preceded by a reduction in BM RIII and RIV erythroid precursor frequency on day 6, highlighting an erythroid differentiation defect in Riok2 haploinsufficient mice (Fig. 1e, Extended Data Fig. 2f). In line with a role for RIOK2 in driving erythroid differentiation, fewer CFU-e colonies were observed in erythropoietin-containing MethoCult cultures from Riok2 haploinsufficient $\mathrm{Lin}^{-} \mathrm{c}-\mathrm{kit}{ }^{+} \mathrm{CD} 71^{+}$cells compared to Riok 2 sufficient cells (Fig. 1f). To determine whether Riok2 haploinsufficiency in BM cells drives anemia, we generated BM chimeras. Wild-type (WT) mice transplanted with Riok $2^{\mathrm{f} /+} \operatorname{Vav}^{\mathrm{cre}}$ whole BM developed anemia compared to Riok $2^{+/+} \operatorname{Vav}^{\text {cre }} \mathrm{BM}$ transplanted wt mice (Extended Data Fig. 2g). In addition, tamoxifen-inducible deletion of Riok2 in $R i o k 2^{\mathrm{f} /+} \mathrm{Ert} 2^{\text {ree }}$ mice led to reduction in PB RBCs, Hb, and HCT compared to Riok $2^{+/+}$Ert 2 re controls (Extended Data Fig. 2h). Taken together, these data show that Riok2 haploinsufficiency leads to anemia owing to defective bone marrow erythroid differentiation.

\section{Riok2 haploinsufficiency increases myelopoiesis}

In addition to the reduction in RBC numbers in PB from aged $R$ iok $2^{\mathrm{f} /+}$ Vav $1^{\text {cre }}$ mice, we also observed an increased percentage of monocytes (monocytosis) and decreased percentage of neutrophils (neutropenia) compared to controls (Fig. 1g, Extended Data Fig. 2i).

Granulocyte macrophage progenitors (GMPs) in the BM give rise to PB myeloid cells. The percentage of proliferating $\left(\mathrm{Ki} 7^{+}\right)$GMPs in the BM was increased in $R i o k 2^{f /+} \operatorname{VaV}^{\text {cre }}$ mice compared to Riok $2^{+/+}$Vav $^{\text {cre }}$ controls (Fig. 1h, Extended Data Fig. 2j). To analyze the effect of Riok 2 haploinsufficiency on myelopoiesis in the absence of in vivo compensatory mechanisms, we cultured LSK (lineage ${ }^{-} \mathrm{Sca}-1^{+} \mathrm{Kit}^{+}$) cells from the BM of $R$ iok $2^{\mathrm{f} /+}$ Vav ${ }^{\text {cre }}$ and $\mathrm{Riok}^{+/+} \mathrm{Vav}^{\mathrm{cre}}$ controls in a MethoCult assay supplemented with growth factors (interleukin 6 (IL-6), IL-3, stem cell factor (SCF) but devoid of erythropoietin). LSKs from Riok $2^{\mathrm{f} /+} \operatorname{Vav}^{\text {cre }}$ mice gave rise to an increased percentage of $\mathrm{CD} 11 \mathrm{~b}^{+}$myeloid cells (Fig. 1i, 
Extended Data Fig. 2k), suggesting a cell-intrinsic myeloproliferative effect due to Riok2 haploinsufficiency consistent with a myelodysplasia phenotype.

We also evaluated whether Riok 2 haploinsufficiency affects early hematopoietic progenitors. Frequency and numbers of early hematopoietic progenitors were comparable between young Riok ${ }^{\text {I/+ }}$ Vav $^{\text {cre }}$ and Riok2 ${ }^{+/+}$Vav $^{\text {ree }}$ mice (Extended Data Fig. 3a), however, long-term hematopoietic stem cells (LT-HSCs) were increased in the BM of aged Riok $2^{\text {f/+ }}$ Vav $^{\text {rre }}$ mice (Extended Data Fig. 3a). To further corroborate this data, we analyzed the capacity of Riok2 haploinsufficient cells in a competitive transplantation assay. Starting at 8 weeks after tamoxifen treatment to induce Riok2 deletion, Riok 2 haploinsufficient cells out-competed CD45.1 ${ }^{+}$competitor cells, while Ert2re control cells had no competitive advantage (Extended Data Fig. 3b). Similar to non-transplanted mice (Extended Data Fig. 3a), in competitive transplant experiments the frequency of Riok2-haploinsufficient LT-HSCs was significantly higher than Riok2-sufficient LT-HSCs in relation to competitor CD45.1 $1^{+}$cells (Extended Data Fig. 3c). Thus, in addition to its effect on erythroid differentiation, Riok2 haploinsufficiency increases myelopoiesis and affects early hematopoietic progenitor differentiation.

\section{Reduced Riok2 induces alarmins in erythroid precursors}

To elucidate a mechanism for the erythroid differentiation defect observed in Riok ${ }^{f /+} \operatorname{Vav}{ }^{\text {cre }}$ mice, we performed quantitative proteomic analysis of purified erythroid precursors using mass spectrometry ${ }^{30}$. Riok 2 haploinsufficiency led to upregulation of 564 distinct proteins (adjusted $p$-value $<0.05$ ) in erythroid precursors compared to those from Vav ${ }^{\text {cre }}$ controls (Fig. 2a). Interestingly, Riok 2 haploinsufficiency resulted in downregulation of other ribosomal proteins, loss of some of which (RPS5, PRL11) has been implicated in driving anemias (Extended Data Fig. 4a). The alarmins including S100A8, S100A9, CAMP, NGP, and others were the most highly upregulated proteins in our dataset and interestingly, correlated significantly with those observed upon haploinsufficiency of $R p s 14^{10}$, another component of the 40S ribosomal complex (Fig. 2b). Using the 26 upregulated proteins in the Rps14 haploinsufficient dataset as an 'Rps14 signature' (Supplementary Table 1), gene set enrichment analysis (GSEA) revealed a marked enrichment for the Rps14 signature in the Riok2 haploinsufficient dataset, suggesting a shared proteomic signature upon deletion of distinct ribosomal proteins (Fig. 2c). The increased expression of S100A8 and S100A9 in Riok $2^{\mathrm{f} /+}$ Vav $^{\text {cre }}{ }^{\text {mice }}$ was confirmed by flow cytometry and qRT-PCR (Extended Data Fig. 4b-e).

In Riok $^{\mathrm{f} /+} \operatorname{Vav}^{\mathrm{cre}}$ erythroid precursors cells, the upregulated proteins with the highest foldchange (S100A8, S100A9, CAMP, NGP) are proteins with known immune functions such as antimicrobial defense. GSEA analysis of the proteomics data indicated a possible role for the immune system in driving the proteomic changes seen in Riok 2 haploinsufficient erythroid precursors (Fig. 2d). An independent analysis of the Riok2 proteomics dataset using MetaCore pathway analysis software showed immune response as the top differentially regulated pathway in $\operatorname{Riok}^{\mathrm{f} /+} \operatorname{VaV} \mathrm{C}^{\mathrm{cre}}$ mice (Fig. 2e). To assess if Riok2 haploinsufficiency leads to changes in immune cell function, we subjected naïve $\mathrm{T}$ cells from Riok $2^{\mathrm{f} /+} \operatorname{Vav}^{\text {cre }}$ mice and Riok $2^{+/+} \operatorname{Vav}^{\text {cre }}$ controls to in vitro polarization towards 
known $\mathrm{CD}^{+} \mathrm{T}$ helper cell lineages $\left(\mathrm{T}_{\mathrm{H}} 1, \mathrm{~T}_{\mathrm{H}} 2, \mathrm{~T}_{\mathrm{H}} 17, \mathrm{~T}_{\mathrm{H}} 22\right)$ and regulatory $\mathrm{T}$ cells $\left(\mathrm{T}_{\text {reg }}\right)$. Secretion of interferon- $\gamma$ (IFN- $\gamma$ ), IL-2, IL-4, IL-5, IL-13, IL-17A, and the frequency of Foxp $3^{+} \mathrm{T}_{\text {reg }}$ cells was similar between Riok $2^{\mathrm{fl+}}$ Vav $^{\text {cre }}$ and Riok $2^{+/+}$Vav $^{\text {cre }} \mathrm{T}$ cells (Extended Data Fig. 5a - g). Strikingly, however, we observed an exclusive increase in IL-22 secretion from $\operatorname{Riok}^{\mathrm{f} /+} \operatorname{Vav}{ }^{\text {cre }}$ naïve $\mathrm{T}$ cells polarized towards the $\mathrm{T}_{\mathrm{H}} 22$ lineage (Fig. 3a).

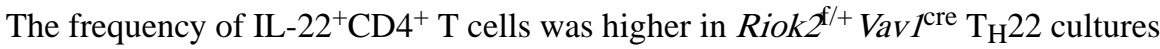
compared to $\operatorname{Vavl}^{\text {cre }}$ control $\mathrm{T}_{\mathrm{H}} 22$ cultures (Fig. 3b). The concentration of IL-22 in the serum and BM fluid (BMF) of aged Riok $2^{\mathrm{f} /+} \operatorname{Vav}^{\mathrm{cre}}$ mice was also significantly higher as compared to age-matched $\mathrm{Vav}^{\text {cre }}$ controls (Fig. 3c). Using known IL-22 target genes from the literature, we curated an 'IL-22 signature' (Supplementary Table 1) gene set, which showed a statistically significant enrichment in the Riok2-haploinsufficient proteomics dataset using GSEA (Fig. 2f), further suggesting that IL-22-induced inflammation is a contributing factor for Riok2 haploinsufficiency-mediated ineffective erythropoiesis and anemia. Increased numbers of splenic IL- $22^{+} \mathrm{CD}^{+} \mathrm{T}$, natural killer T (NKT), and innate lymphoid cells (ILCs) were observed in aged $R i o k 2^{\mathrm{f} /+} \operatorname{Vav}^{\text {cre }}$ mice compared to Riok $2^{+++}$Vav $^{\text {cre }}$ mice (Fig. 3d, Extended Data Fig. 5h, i). Interestingly, mild anemia was observed in mice lacking Riok 2 only in T cells (Extended Data Fig. 5k). Expression of IL-23, required for IL-22 production, was enhanced in Riok2-haploinsufficient dendritic cells (Extended Data Fig. 5j). Rps 14 haploinsufficient $\mathrm{T}_{\mathrm{H}} 22$ cells also secreted elevated concentrations of IL-22 compared to Vav ${ }^{\text {cre }}$ control $\mathrm{T}_{\mathrm{H}} 22$ cells (Extended Data Fig. 51). Mutation(s) in the gene adenomatosis polyposis coli $(A p c)$, also found on human chromosome 5q, lead to anemia in addition to adenomas ${ }^{31}$. In vitro generated $\mathrm{T}_{\mathrm{H}} 22$ cells from $A p c^{\mathrm{Min}}$ mice secreted elevated IL-22 compared to littermate controls (Extended Data Fig. $5 \mathrm{~m}$ ). In total, our analysis of three distinct heterozygous deletions of genes found on human chromosome 5q suggests that increased IL-22 is a generalized phenomenon observed upon heterozygous loss of genes found on chromosome $5 q$ leading to anemia.

\section{p53 upregulation drives increased IL-22 secretion upon Riok2 loss}

To identify cell-intrinsic molecular mechanism(s) driving the increase in IL-22 secretion upon Riok2 haploinsufficiency, we performed RNA-sequencing (RNA-Seq) on in vitro polarized IL-22+ $\left(\mathrm{T}_{\mathrm{H}} 22\right)$ cells purified by flow cytometry from Riok $2^{+/+} I I 22^{\text {dtomato/+ }}$ Vav $1^{\text {cre }}$ and Riok $^{\mathrm{f} / \mathrm{+}} I 122^{\text {tdtomato/+ }}$ Vav $^{\text {cre }}$ mice (Fig. 3e). GSEA analysis of the RNA-Seq dataset identified activation of the p53 pathway in $R i o k 2^{\mathrm{f} /+} \operatorname{Vav}^{\text {cre }}$ mice (Fig. 3f, g). p53 increase in $\mathrm{T}_{\mathrm{H}} 22$ cells from $\operatorname{Riok}^{\mathrm{f} /+} \operatorname{Vav} 1^{\text {cre }}$ mice was confirmed by flow cytometry (Fig. 3h, i). p53 upregulation was also observed in $R i o k 2^{f /+} \operatorname{VaV}{ }^{\text {cre }}$ erythroid precursors (Extended Data Fig. $3 \mathrm{f}, \mathrm{g}$ ). The $\mathrm{p} 53$ pathway is activated by decreased expression of ribosomal protein genes $5 ; 10$, however, its involvement in IL-22 regulation has not been known.

p53 is a transcription factor with well-defined consensus binding sites. To assess whether p53 drives $I I 22$ transcription, we analyzed the $I 122$ promoter for potential p53 binding sites using LASAGNA algorithm and found putative p53 consensus binding sequences in the II22 promoter (Fig. 3j). Chromatin immunoprecipitation (ChIP) confirmed the presence of p53 on the $I 122$ promoter (Fig. 3k). In line with the ChIP data, p53 inhibition by pifithrin-a, pnitro decreased IL-22 concentrations while p53 activation by nutlin-3 increased IL-22 from in vitro polarized wild-type $\mathrm{T}_{\mathrm{H}} 22$ cells (Fig. 31, m). Treatment with either pifithrin-a, p-nitro 
or nutlin-3 did not decrease cell viability (Extended Data Fig. 5n). Accordingly, genetic deletion of Trp53 blunted the increase in IL-22 secretion observed upon Riok2 haploinsufficiency (Fig. 3n). A significant decrease in IL-22 secretion was also observed upon Trp53 deletion in Riok2-sufficient cells further suggesting a homeostatic role for p53 in controlling IL-22 production (Fig. 3n). Taken together, these data show that Riok2 haploinsufficiency-mediated p53 upregulation drives increased IL-22 secretion in Riok $2^{\mathrm{f} /+}$ Vav1 $^{\text {cre }}$ mice.

\section{IL-22 neutralization alleviates stress-induced anemia}

Mice with compound genetic deletion of II22 on the Riok 2 haploinsufficient background ( Riok $^{\mathrm{f} /+} I I 22^{+/-} \mathrm{VaV}^{\mathrm{cre}}$ ) exhibited increased numbers of PB RBCs compared to IL-22 sufficient Riok 2 haploinsufficient mice on day 7 after two treatments with $25 \mathrm{mg} / \mathrm{kg}$ phenylhydrazine treatment (Fig. 4a). Interestingly, we also saw an increase in PB RBCs in Riok 2 sufficient mice heterozygous for $I 122$ deletion $\left(\right.$ Riok $\left.^{+/+} \mathrm{II}_{2} 2^{+/-} \mathrm{VaV}^{\mathrm{cre}}\right)$ compared to Riok 2 sufficient IL-22 sufficient mice ( iiok $\left.^{+/+} I I 22^{+/+} \operatorname{VaV}{ }^{\mathrm{cre}}\right)$. PB Hb and HCT also were increased in II22 haploinsufficient mice, regardless of Riok 2 background, however, this difference did not reach statistical significance (Fig. 4a). Next, we assessed whether the

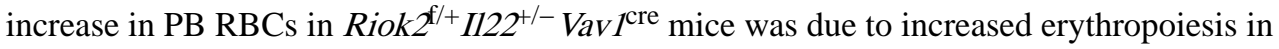
the BM of these mice. We observed an increase in RII and RIV erythroid precursors in

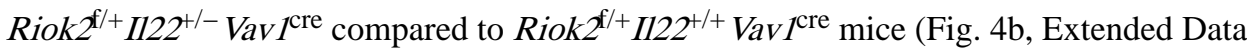
Fig. 6a). Treatment of mice with a neutralizing IL-22 antibody in vivo, also reversed phenylhydrazine-induced anemia as evidenced by increase in PB RBCs and HCT in Riok $2^{\mathrm{f} /+} \operatorname{Vav}^{\mathrm{cre}}$ mice as well as Riok2 sufficient (Riok $\left.2^{+/+} \operatorname{Vav}^{\mathrm{cre}}\right)$ mice (Fig. 4c). Unexpectedly, IL-22 neutralization also reduced the frequency of apoptotic erythroid precursors in both Riok 2 sufficient as well as Riok $2^{\mathrm{f} /+} \operatorname{Vav}^{\text {cre }}$ mice (Fig. 4d). These data indicate that IL-22 neutralization reverses anemia, at least in part, by reducing apoptosis of erythroid precursors. Recently, dampening IL-22 signaling in intestinal epithelial stem cells was shown to reduce apoptosis ${ }^{32}$. The effect of IL-22 deficiency (genetic as well as antibody-mediated) in alleviating anemia in genetically wild-type mice indicated a role for IL-22 in reversing anemia regardless of ribosomal haploinsufficiency. Accordingly, treatment of C57BL/6J mice undergoing phenylhydrazine-induced anemia with anti-IL-22 significantly increased PB RBCs, Hb, and HCT compared to isotype antibody-treated mice (Extended Data Fig. 7b). This increase in PB RBCs could be attributed to the increased frequency of RIII and RIV erythroid precursors in the BM of mice treated with anti-IL-22 compared to isotype-administered controls (Extended Data Fig. 7c). Of note, PB RBCs, Hb, and HCT did not differ in healthy, non-anemic wild-type mice injected with anti-IL-22 versus isotype-matched antibody (Extended Data Fig. 7a). Thus, we show here that IL-22 neutralization, either by genetic deletion or antibody blockade, alleviates stress-induced anemia in $\mathrm{Riok}^{\mathrm{f} /+} \mathrm{Vav}^{\mathrm{cre}}$ as well as wild-type mice.

\section{IL-22 worsens stress-induced anemia in wild-type mice}

Phenylhydrazine administration to wild-type C57BL/6J mice treated intraperitoneally with recombinant IL-22 (rIL-22) led to decreased PB RBCs, Hb, and HCT owing to decreased BM erythroid precursor cell frequency and number (Fig. 5a, c, Extended Data Fig. 6b). rIL-22 treatment led to increased apoptosis of erythroid precursors (Fig. 5d). This treatment 
also led to an increase in PB reticulocytes, an indication of increased erythropoiesis under stress (Fig. 5b). Recombinant IL-22 also dose-dependently decreased terminal erythropoiesis in an in vitro erythropoiesis assay (Fig. 5e, f). Importantly, IL-22-mediated inhibition of in vitro erythropoiesis led to induction of p53 suggesting a feedback loop between IL-22 and p53 in driving dyserythropoiesis (Fig. 5g). Overall, these data show that exogenous recombinant IL-22 exacerbates stress-induced anemia in wild-type mice.

\section{Erythroid precursors express IL-22RA1 receptors}

IL-22 signals through a cell surface heterodimeric receptor composed of IL-10R $\beta$ and IL-22RA1 (encoded by II22raI) ${ }^{33}$. IL-22RA1 expression has been reported to be restricted to cells of non-hematopoietic origin (e.g., epithelial cells and mesenchymal cells). We discovered, however, that erythroid precursors in the BM also express IL-22RA1 (Fig. 6a, Extended Data Fig. 8a). Moreover, we observed that among BM hematopoietic progenitors, IL-22RA1-expressing cells were exclusively of the erythroid lineage (Extended Data Fig. $8 b)$. Using a second IL-22RA1-specific antibody (targeting a different epitope than the antibody used in Fig. 4A), we confirmed the presence of IL-22RA1 on erythroid precursors (Extended Data Fig. 8c). II22ra1 mRNA expression was detected exclusively in erythroid precursors among all lineage-negative cells in the BM (Extended Data Fig. 8d).

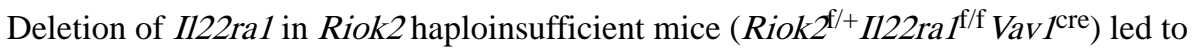
improvement in PB RBCs and HCT as compared to IL-22RA1 sufficient Riok2 haploinsufficient mice ( iiok $^{\mathrm{f} /+} I I 22 \mathrm{raI}^{+/+} \operatorname{VaV}^{\text {cre }}$ ) (Fig. 6b). This improvement could be attributed to the increase in RIII and RIV erythroid precursors in the BM of Riok $2^{\mathrm{f} /+}$ II22ra $1^{\mathrm{f} / \mathrm{f}} \operatorname{Vav}{ }^{\mathrm{cre}}$ mice (Fig. 6c, Extended Data Fig. 6c).

In accordance with the upregulation of p53 upon in vitro IL-22 stimulation in an in vitro erythropoiesis assay (Fig. 5g) and p53 upregulation in erythroid precursors upon Riok2 haploinsufficiency (Extended Data Fig. 4f, g), we observed a synergistic effect of Riok2 haploinsufficiency in IL-22-responsive (IL-22RA1 ${ }^{+}$) erythroid precursors in Riok $2^{\mathrm{f} /+} \operatorname{Vav}^{\text {cre }}$ mice (Fig. 6d, e). p53 target genes such as Gadd45a and Cdkn1a1 were also increased in IL-22RA1 ${ }^{+}$Riok2 haploinsufficient erythroid precursors compared to IL-22RA1 ${ }^{+}$Riok2 sufficient erythroid precursors (Fig. 6f). Given that rIL-22 induced apoptosis in erythroid precursors in vivo (Fig. 5d), we sought to determine if Riok2 haploinsufficiency-mediated p53 upregulation played an independent role in apoptosis induction. In an IL-22-free in vitro erythropoiesis assay, p53 inhibition by pifithrin-a, p-nitro inhibited the apoptosis induced by Riok2 haploinsufficiency (Fig. 6g).

Erythroid cell-specific deletion of IL-22RA1 (using cre recombinase driven by the erythropoietin receptor (Epor) promoter) also increased numbers of PB RBCs and HCT (Fig. 7a) due to the increase in RIII and RIV erythroid precursors in the BM (Fig. 7b, Extended Data Fig. 6d). Additionally, rIL-22 failed to exacerbate phenylhydrazine-induced anemia in II22ra ${ }^{\mathrm{f} / \mathrm{f}}$ Epor ${ }^{\mathrm{cre}}$ mice lacking the IL-22 receptor only on erythroid cells (Fig. 7c). These data reinforce our view that IL-22 signaling plays an important role in regulating erythroid development regardless of ribosomal haploinsufficiency. Thus, using three different approaches to neutralize IL-22 signaling, we demonstrate that IL-22 plays a critical role in controlling RBC production by directly regulating early stages of erythropoiesis. 


\section{IL-22 is increased in del(5q) MDS patients}

Next, we assessed whether IL-22 expression is increased in human disorders that display dyserythropoiesis due to ribosomal protein haploinsufficiencies. Given the localization of RIOK2 on human chromosome 5, we focused on MDS with 5q deletion and compared it to MDS without $5 q$ deletion and healthy controls. We observed a significant increase in IL-22 levels in the BM fluid (BMF) of del(5q) MDS patients compared to BMF from healthy controls and non-del(5q) MDS patients (Fig. 8a). Interestingly, a strong negative correlation between cellular RIOK2 mRNA expression and BMF IL-22 concentration was evident in the $\operatorname{del}(5 q)$ MDS cohort (Fig. 8b) indicating that a decrease in RIOK2 expression is associated with increased IL-22 expression. In our MDS cohort, S100A8 concentrations were found to be higher than healthy controls regardless of del(5q) status (Fig. 8c). However, IL-22 positively correlated with S100A8 concentrations only in the del(5q) MDS group (Fig. 8d). Of note, S100A8 concentrations were higher in BMF from non-del(5q) MDS patients compared to MDS patients with del(5q) (Fig. 8c). These data suggest that the regulation of S100A8 expression may be IL-22-mediated in del(5q) MDS patients, but IL-22-independent in other subtypes of MDS. In a second cohort of MDS patients, the frequency of CD4 ${ }^{+} \mathrm{T}$ cells producing IL-22 ( $\mathrm{T}_{\mathrm{H}} 22$ cells) among freshly isolated peripheral blood mononuclear cells (PBMCs) was significantly higher in MDS patients with 5q deletion compared to healthy controls (Fig. 8e - cumulative data of representative flow plots shown in Extended Data Fig. 9a). Our independent analysis of a large-scale microarray sequencing dataset of $\mathrm{CD}^{2} 4^{+}$cells from normal, del(5q) MDS, and non-del(5q) MDS subjects showed that RIOK2 mRNA was significantly decreased in the del(5q) MDS cohort (78\% (37/47)). Additionally, expression of known IL-22 target genes such as S100A10, S100A11, PTGS2, RAB7A, and $L C N 2$ was specifically increased in the $\operatorname{del}(5 \mathrm{q})$ MDS cohort compared to both the healthy control and non-del(5q) groups (Extended Data Fig. 9b). Using differentially expressed proteins (adjusted p-value $<0.01$ ) from the Riok 2 haploinsufficient proteomics dataset as a reference set, GSEA analyses of the $\mathrm{CD} 34^{+}$microarray dataset revealed significant enrichment scores (Extended Data Fig. 10a, b) further suggesting that the mouse model of Riok2 haploinsufficiency faithfully recapitulates the molecular changes seen in patients with $\operatorname{del}(5 q)$ MDS.

\section{High IL-22 in anemic chronic kidney disease patients}

Anemia is frequently observed in CKD patients and is associated with poor outcomes. Anemia of CKD is resistant to erythropoiesis-stimulating agents (ESAs) in 10-20\% of patients ${ }^{34}$, suggesting that pathogenic mechanisms other than erythropoietin deficiency are at play. We found a significant increase in IL-22 concentration in the plasma of CKD patients with secondary anemia compared to healthy controls and to CKD patients without anemia (Fig. 8f). Plasma IL-22 concentration negatively correlated with hemoglobin in CKD patients (Fig. 8g), suggesting a function for IL-22 in driving anemia in some patients with CKD.

\section{Discussion}

The overall conclusion of this study is that IL-22 signaling directly controls bone marrow erythroid differentiation and that its neutralization is a potential therapeutic approach for 
anemias and MDS. By exploring the function of a little-studied atypical kinase Riok2 in mammalian biology, we identified the erythroid precursors as a novel target for IL-22 action via the IL-22RA1. We further identify IL-22 as a disease biomarker for the del(5q) subtype of MDS and lastly, identify IL-22 signaling blockade as a potential therapeutic for stressinduced anemias irrespective of the genetic background. Interestingly, we also detect elevated levels of IL-22 in patients with anemia secondary to chronic kidney disease (CKD) suggesting that IL-22 signaling blockade may be therapeutic in reversing anemia in a much wider patient population.

$\operatorname{Del}(5 \mathrm{q})$, either isolated or accompanied by additional cytogenetic abnormalities, is the most commonly detected chromosomal abnormality in MDS, reported in 10-15\% of patients and enriched in therapy-related MDS. The severe anemia in MDS patients with isolated del(5q) has been linked to haploinsufficiency of ribosomal proteins such as RPS14 ${ }^{10}$ and RPS19 ${ }^{5}$. While much research has focused on the effect of such gene deletions or mutations in hematopoietic stem cells and lineage-committed progenitors, the immunobiology underlying this MDS subtype has remained largely unexplored, thus impeding the development of immune-targeted therapies. With the exception of the TNF-a inhibitor etanercept ${ }^{35}$ which proved to be ineffective, the only other therapy against immune cell-derived cytokines, is luspatercept ${ }^{36}$, a recombinant fusion protein derived from human activin receptor type $\mathrm{IIb}^{37}$ which has just been approved for use in anemia in lower risk MDS patients. Here, we identify two critical and independent functions of an understudied atypical kinase, RIOK2, that synergize to induce dyserythropoiesis and anemia. One effect of Riok 2 loss in erythroid precursors is an intrinsic block in erythroid differentiation owing to its indispensable role in the maturation of the pre-40S ribosomal complex, leading to increased apoptosis and cell cycle arrest. The second effect of Riok2 loss is the induction of the erythropoiesissuppressive cytokine IL-22 in T cells which then directly acts on the IL-22RA1 on erythroid precursors (Extended Data Fig. 10c). While IL-22RA1 is known to be widely expressed on epithelial cells and hepatocytes, its expression has also been recently reported on specialized cells such as retinal Müller glial cells ${ }^{38}$ and now described here, on erythroid precursors. Our data reveal a novel molecular link between haploinsufficiency of a ribosomal protein and induction of erythropoiesis-suppressive cytokine IL-22. While IL-22 has been shown to modulate RBC production by controlling the expression of iron-chelating proteins such as hepcidin ${ }^{39}$ and haptoglobin ${ }^{40}$, we have uncovered a novel role for IL-22 in directly binding to the previously unknown IL-22R on erythroid precursors leading to their apoptosis. Diminished expression of ribosomal proteins has been shown to increase p53 levels. We show here that Riok 2 haploinsufficiency leads to p53 upregulation in $\mathrm{T}$ cells which drives the increase in IL-22 secretion. Additionally, we also show that IL-22-responsive erythroid precursors express elevated p53 further suggesting a role for p53 downstream of IL-22 signaling in driving dyserythropoiesis. Using banked and fresh del(5q) MDS and CKD patient samples, we also show that IL-22 is elevated in these human diseases.

The role of inflammatory cytokines in directly regulating various aspects of BM hematopoiesis in steady-state and diseased conditions is increasingly being recognized ${ }^{41-43}$. IL-22 is known to play a pathogenic role in some autoimmune diseases ${ }^{44 ; 45}$. Interestingly, autoimmune diseases such as colitis, Behçet's disease, and arthritis are common in MDS patients, with features of autoimmunity observed in up to $10 \%$ of patients ${ }^{46}$. It is intriguing 
to hypothesize that IL-22 may account both for the onset of MDS and autoimmunity in this subset of patients. Studies have reported that in patients with co-existence of MDS and autoimmunity, treatment for one can alleviate the symptoms of the other ${ }^{47 ; 48}$. Low-level exposure to benzene, a hydrocarbon, has been associated with an increased risk of MDS ${ }^{49}$. Hydrocarbons are known ligands for aryl hydrocarbon receptor (AHR), the transcription factor that controls IL-22 production in T cells. Stemregenin 1, an AHR antagonist, was shown to promote the ex vivo expansion of human HSCs, with the highest fold expansion seen in the erythroid lineage ${ }^{50}$. Overall, these observations suggest that inhibition of the AHR-IL-22 axis may be an attractive approach for treating red blood cell disorders that arise from dyserythropoiesis.

Further, we provide evidence that neutralization of IL-22 signaling may be effective not only in the treatment of MDS and other stress-induced anemias, but also in the anemia of chronic diseases such as CKD, which are very much in need of new therapeutic approaches. With currently approved MDS therapies (lenalidomide and other hypomethylating agents, erythropoiesis-stimulating agents), the survival time of MDS patients after diagnosis is only 2.5-3 yrs. Patients also develop resistance to these therapies thus intensifying the need for additional therapeutic modalities. IL-22-based therapies could be used in conjunction with already existing therapeutics or after first-line therapies have failed due to acquisition of resistance.

\section{METHODS}

\section{Human samples and processing}

MDS and CKD patient samples were collected under IRB-approved protocols at DanaFarber Cancer Institute (DFCI) and Brigham and Women's Hospital (BWH), respectively. All samples were de-identified at the time of inclusion in the study. All patients provided informed consent and the data collection was performed in accordance with the Declaration of Helsinki.

Peripheral blood mononuclear cells (PBMCs) from EDTA-treated whole blood were isolated using density gradient centrifugation. PBMCs were then incubated in RPMI with 10\% FBS and Cell Activation Cocktail (Tonbo Biosciences) for $4 \mathrm{~h}$ and then processed for flow cytometry as described below. Relevant clinical information of MDS samples is provided in Supplemental Table Adult CKD plasma samples were stored at $-80{ }^{\circ} \mathrm{C}$ until further use. Relevant clinical information of CKD samples is provided in Supplemental Table 3.

\section{Generation of Riok2 floxed mice}

Riok $2^{\mathrm{f} / \mathrm{f}}$ mice were generated using frozen sperm obtained from Mutant Mouse Resource and Research Centers (MMRRC) (Riok2 $\left.2^{\mathrm{m} 1 \mathrm{a}(\mathrm{KOMP}) \mathrm{Wtsi}}\right)^{51}$. In brief, a floxed Riok2 allele was created by inserting an FRT-flanked IRES-LacZ-neor cassette into intron 4 of the Riok2 gene. LoxP sites were inserted to flank exons 5 and 6. After germline transmission, the FRT cassette was removed by crossing to FLPe deleter mice ${ }^{52}$ and resulting floxed mice were bred with individual cre driver strains to create conditional Riok2-deleted mice (Extended 
Data Fig. 1a). Genotyping (Extended Data Fig. 1c) was carried out using the following primers:

Forward primer: 5' GCATCAGTGATTTACAGACTAAAATGCC 3'

Reverse primer 1: 5' GCTCTTACCCACTGAGTCATCTCACC 3'

Reverse primer 2: 5' CCCAGACTCCTTCTTGAAGTTCTGC 3'

\section{Mice}

Wild-type C57BL/6J mice (Stock no. 000664), Vav-icre mice (Stock no. 008610), R26CreErt2 mice (Stock no. 008463), Il22ral-floxed (Stock no. 031003), CD45.1 C57BL/6J mice (Stock no. 002014), Trp53-/- (Stock no. 002101), Cd4-cre (Stock no. 022071), and

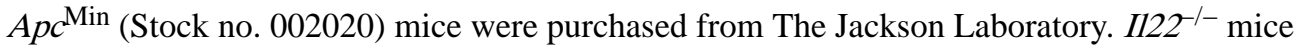
were provided by R. Caspi (National Institutes of Health, Bethesda, MD) with permission from Genentech (San Francisco, CA). Epor-cre ${ }^{53}$ mice were a gift from U. Klingmüller (Deutsches Krebsforschungszentrum (DFKZ), Germany). Il22-tdtomato (Catch-22) ${ }^{54}$ mice were a gift from R. Locksley (University of California at San Francisco, CA). Rps14floxed mice $^{55}$ were a gift from B. Ebert (Dana-Farber Cancer Institute, Boston, MA). Mice were housed in the Animal Research Facility (ARF) at DFCI under ambient temperature and humidity with $12 \mathrm{~h}$ light/12 h dark cycle. Animal procedures and treatments were in compliance with the guidelines set forth by the Institutional Animal Care and Use Committee (IACUC) at DFCI. Age- and gender- matched mice were used within experiments.

\section{Competitive bone marrow (BM) transplantation}

$2 \times 10^{6}$ freshly isolated BM cells from CD $45.2^{+} \operatorname{Riok}^{\mathrm{f} /+} \mathrm{Ert}^{\mathrm{cre}}$ or $\mathrm{Riok}^{+/+} \mathrm{Ert}^{\mathrm{xre}}$ mice were transplanted in competition with $2 \times 10^{6}$ freshly isolated CD45.1 $1^{+}$wild-type (WT) BM cells via retro-orbital injection into lethally irradiated 8-10 week old CD45.1 ${ }^{+}$WT recipient mice. The donor cell chimerism was determined in the peripheral blood four weeks after transplantation before the excision of Riok 2 was induced by tamoxifen injection as well as every four to eight weeks as indicated. Tamoxifen $(75 \mathrm{mg} / \mathrm{kg}$ ) (Cayman Chemical, Cat \# 13258) was administered for five consecutive days.

\section{Flow cytometry and cell isolation}

Whole bone marrow (BM) cells were isolated by crushing hind leg bones (femur and tibia) with mortar and pestle in staining buffer (PBS (Corning) supplemented with 2\% heatinactivated fetal bovine serum (FBS, Atlanta Biologicals) and EDTA (GIBCO). Whole BM was lysed with 1X PharmLyse (BD Biosciences) for $90 \mathrm{~s}$, and the reaction was terminated by adding an excess of staining buffer. Cells were labeled with fluorochrome-conjugated antibodies in staining buffer for $30 \mathrm{~min}$ at $4{ }^{\circ} \mathrm{C}$. For flow cytometric analysis, cells were incubated with combinations of fluorochrome-conjugated antibodies to the following cell surface markers: CD3 (17A2, 1:500), CD5 (53-7.3, 1:500), CD11b (M1/70, 1:500), Gr1 (RB6-8C5, 1:500), B220 (RA3-6B2, 1:500), Ter119 (TER119, 1:500), CD71 (C2, 1:500), c-kit (2B8, 1:500), Sca-1 (D7, 1:500), CD16/32 (93, 1:500), CD150 (TC15-12F12.2, 1:150), 
CD48 (HM48-1, 1:500). For sorting of lineage-negative cells, lineage markers included CD3, CD5, CD11b, Gr1 and Ter119. For sorting erythroid progenitor cells, the lineage cocktail did not include Ter119. All reagents were acquired from BD Biosciences, Thermo Fisher Scientific, Novus Biologicals, Tonbo Biosciences, or BioLegend. Identification of apoptotic cells was carried out using the Annexin V Apoptosis Detection Kit (BioLegend). Intracytoplasmic and intranuclear staining was performed using Foxp3/Transcription Factor Staining Kit (Thermo Fisher Scientific) or 0.1\% saponin in PBS supplemented with 3\% FBS. For staining performed with AF647 p53 antibody (Cell Signaling Technology, 1:50), cells were permeabilized with $90 \%$ ice-cold methanol. To increase the sorting efficiency, whole BM samples were lineage-depleted using magnetic microbeads (Miltenyi Biotec) and autoMACS Pro magnetic separator (Miltenyi Biotec). Cell sorting was performed on a FACS Aria flow cytometer (BD Biosciences), data acquisition was performed on a BD Fortessa X-20 instrument equipped with 5 lasers (BD Biosciences) employing FACSDiva software. Data were analyzed by FlowJo (Tree Star) version 9 software. Flow analyses were performed on viable cells by exclusion of dead cells using either DAPI or a fixable viability dye (Tonbo Biosciences). Gating for early and committed hematopoietic progenitors was performed as described elsewhere ${ }^{56}$. ILCs and NKT cells were identified as Lin ${ }^{-} \mathrm{CD} 45^{+} \mathrm{CD} 90^{+} \mathrm{CD} 12^{+}$and $\mathrm{CD} 3 \varepsilon^{+} \mathrm{NK} 1.1^{+}$, respectively.

\section{Complete blood count}

Mice were bled via the submandibular facial vein to collect blood in EDTA-coated tubes (BD Microtainer ${ }^{\mathrm{TM}}$ Capillary Blood Collector, BD 365974). Complete blood counts were obtained using the HemaVet CBC Analyzer (Drew Scientific) or Advia 120 (Siemens Inc.,) instruments.

\section{In vivo measurement of protein synthesis}

$100 \mu \mathrm{L}$ of a $20 \mathrm{mM}$ solution of O-Propargyl-Puromycin (OP-Puro; BioMol) was injected intraperitoneally in mice and mice were then rested for $1 \mathrm{~h}$. Mice injected with PBS were used as controls. BM was harvested after $1 \mathrm{~h}$ and stained with antibodies against cell surface markers, washed to remove excess unbound antibodies, fixed in $1 \%$ paraformaldehyde, and permeabilized in PBS with 3\% FBS and $0.1 \%$ saponin. The azide-alkyne cyclo-addition was performed using the Click-iT Cell Reaction Buffer Kit (Thermo Fisher Scientific) and azide conjugated to Alexa Fluor 647 (Thermo Fisher Scientific) at $5 \mu \mathrm{M}$ final concentration for 30 min. Cells were washed twice and analyzed by flow cytometry. 'Relative rate of protein synthesis' was calculated by normalizing OP-Puro signals to whole bone marrow after subtracting autofluorescence.

\section{Methylcellulose assay}

$250-500 \mathrm{BM} \mathrm{Lin}^{-} \mathrm{c}-\mathrm{kit}^{+} \mathrm{Sca}-1^{+}$cells were flow sorted and plated in semi-solid methylcellulose culture medium (M3534, StemCell Technologies) and incubated at $37{ }^{\circ} \mathrm{C}$ in a humidified atmosphere for 7-10 days. At the end of the incubation period, each well was triturated with staining buffer to collect cells and then processed for flow cytometry as described above. Enumeration of colonies in MethoCult media was performed with StemVision instrument StemCell Technologies). 


\section{Phenylhydrazine treatment}

Phenylhydrazine (PhZ) was purchased from Sigma and injected intraperitoneally on 2 consecutive days (days 0 and 1) at the dose of $25 \mathrm{mg} / \mathrm{kg}$ (sublethal model) or $35 \mathrm{mg} / \mathrm{kg}$ (lethal model). Peripheral blood was collected 3-4 days before the start of treatment and at day 4,7 , and 11 . PhZ treatment experiments were carried out in 8-12 week old mice.

\section{T cell polarization}

Single-cell suspensions of mouse spleens were prepared by pressing tissue through a 70- $\mu \mathrm{m}$ cell strainer followed by red blood cell lysis using PharmLyse. Total splenic $\mathrm{CD} 4^{+} \mathrm{T}$ cells were isolated using $\mathrm{CD} 4 \mathrm{~T}$ cell isolation kit (Miltenyi Biotec). Enriched $\mathrm{CD} 4^{+} \mathrm{T}$ cells were then incubated with fluorochrome-conjugated antibodies to CD4, CD8, CD25, CD62L, and $\mathrm{CD} 44$ to purify naïve $\mathrm{CD} 4{ }^{+} \mathrm{T}$ cells using fluorescence activated cell sorting (FACS). In the presence of $1 \mu \mathrm{g} / \mathrm{mL}$ plate-bound anti-CD3 $\varepsilon$ and soluble $1 \mu \mathrm{g} / \mathrm{mL}$ anti-CD28, T cell polarizations were carried out in IMDM supplemented with 10\% FBS, 2mM L-glutamine, $100 \mathrm{mg} / \mathrm{mL}$ penicillin-streptomycin, HEPES (pH 7.2-7.6), non-essential amino acids, 100 $\mu \mathrm{M} \beta$-mercaptoethanol (BME), and sodium pyruvate as follows - $\mathrm{T}_{\mathrm{H}} 1$ (20 ng/mL IL-12, 10 $\mu \mathrm{g} / \mathrm{mL}$ anti-IL-4), $\mathrm{T}_{\mathrm{H}} 2\left(20 \mathrm{ng} / \mathrm{mL}\right.$ IL-4, $10 \mu \mathrm{g} / \mathrm{mL}$ anti-IFN- $\gamma$ ), $\mathrm{T}_{\mathrm{H}} 17$ (30 ng/mL IL-6, 20 $\mathrm{ng} / \mathrm{mL}$ IL-23, $20 \mathrm{ng} / \mathrm{mL}$ IL- $1 \beta, 10 \mu \mathrm{g} / \mathrm{mL}$ anti-IL-4, $10 \mu \mathrm{g} / \mathrm{mL}$ anti-IFN- $\gamma$ ), $\mathrm{T}_{\text {reg }}$ cells ( 1 $\mathrm{ng} / \mathrm{mL}$ TGF- $\beta, 10 \mu \mathrm{g} / \mathrm{mL}$ anti-IL-4, $10 \mu \mathrm{g} / \mathrm{mL}$ anti-IFN- $\gamma$ ), and $\mathrm{T}_{\mathrm{H}} 22(30 \mathrm{ng} / \mathrm{mL}$ IL-6, 20 $\mathrm{ng} / \mathrm{mL}$ IL-23, $20 \mathrm{ng} / \mathrm{mL}$ IL-1 $\beta, 10 \mu \mathrm{g} / \mathrm{mL}$ anti-IL-4, $10 \mu \mathrm{g} / \mathrm{mL}$ anti-IFN- $\gamma, 400 \mathrm{nM}$ FICZ). Pifithrin-a, p-Nitro and Nutlin-3a were purchased from Santa Cruz Biotechnology and Tocris Biosciences, respectively.

\section{IL-22 neutralization and reconstitution}

Monoclonal anti-IL-22 (Clone IL22JOP) blocking antibody and isotype control IgG2ax (Clone eBR2a) were purchased from Thermo Fisher Scientific. Mice were administered antiIL-22 (50 $\mu \mathrm{g} / \mathrm{mouse})$ or isotype intraperitoneally every $48 \mathrm{~h}$ until the conclusion of the experiment. For \recombinant IL-22 treatment, mice were injected with recombinant IL-22 ( $500 \mathrm{ng} /$ mouse; PeproTech) intraperitoneally every $24 \mathrm{~h}$ until the conclusion of the experiment. Mice were administered these reagents at least five times before inducing PhZmediated anemia.

\section{Cytokine quantitation}

IL-22 in human samples was quantified using either Human IL-22 Quantikine ELISA Kit (D2200, R\&D Systems) or SMCTM Human IL-22 High Sensitivity Immunoassay Kit (EMD Millipore, 03-0162-00) according to manufacturers' instructions. The SMC assay was read on a SMC Pro (EMD Millipore) instrument. The lower limit of quantification (LLOQ) of this immunoassay is $0.1 \mathrm{pg} / \mathrm{mL}$. IL-22 in mouse samples was quantified using ELISA MAXTM Deluxe Set Mouse IL-22 (BioLegend, 436304). The LLOQ of this immunoassay is $3.9 \mathrm{pg} / \mathrm{mL}$. S100A8 in human samples was quantified using Human S100A8 DuoSet ELISA (DY4570, R\&D Systems).

Concentration of lineage-associated cytokines in cell culture supernatants of polarized $\mathrm{T}$ cells were quantified using a custom-made ProCarta Plex assay (Thermo Fisher Scientific) acquired on a Luminex platform. Hepcidin in mouse serum was quantified using a 
colorimetric assay from Hepcidin Murine-Compete TM ELISA Kit from Intrinsic

LifeSciences (HMC-001).

\section{mRNA quantitation}

Cells were flow sorted directly into the lysis buffer provided with the Cells-to-CT ${ }^{\mathrm{TM}}$ 1-Step

TaqMan $^{\text {TM }}$ Kit (A25605, Thermo Fisher Scientific) and processed according to the manufacturer's instructions. Pre-designed TaqMan gene expression assays were used to quantify mRNA expression by qPCR using QuantStudio 6 (Thermo Fisher Scientific). Hprt was used as housekeeping control. Relative expression was calculated using the $\Delta \mathrm{Ct}$ method. Please refer to Supplementary Table 4 for primers details.

\section{Chromatin Immunoprecipitation (ChIP)}

ChIP was performed using EZ-ChIP Kit (EMD Millipore) according to manufacturer's instructions. Briefly, cells were fixed and cross-linked with $1 \%$ formaldehyde at $25{ }^{\circ} \mathrm{C}$ for 10 min and quenched with $125 \mathrm{mM}$ glycine for an additional $10 \mathrm{~min}$. Cells pellet was resuspended in lysis buffer and shearing was carried out Diagenode Bioruptor sonication system for a total of 40 cycles beads. Pre-cleared lysates were incubated with control Mouse IgG or anti-p53 (Santa Cruz Biotechnology) antibodies. II22 promoter-specific primer pair was designed using Primer 3.0 Input and were as follows:

Forward Primer: 5' CCAAACTTAACTTGACCTTGGC 3'

Reverse Primer: 5' TTCTTCACAGCTCCCA TTGC 3'

\section{In vitro erythroid differentiation}

Whole BM cells were labeled with biotin-conjugated lineage antibodies (cocktail of antiCD3e, anti-CD11b, anti-CD45R/B220, anti-Gr1, anti-CD5, and anti-TER-119) (BD Pharmingen) and purified using anti-biotin beads and negative selection on the AutoMACS Pro (Miltenyi). Purified cells were then seeded in fibronectin-coated $\left(2 \mu \mathrm{g} / \mathrm{cm}^{2}\right)$ tissueculture treated polystyrene wells (Corning ${ }^{\circledR}$ BioCoat ${ }^{\mathrm{TM}}$ Cellware) at a cell density of $105 / \mathrm{mL}$. Erythroid differentiation was carried out according to modified published protocols ${ }^{57}$. The erythropoietic medium was IMDM supplemented with erythropoietin at 10 $\mathrm{U} / \mathrm{mL}, 10 \mathrm{ng} / \mathrm{mL}$ stem cell factor SCF, PeproTech), $10 \mu \mathrm{M}$ Dexamethasone (Sigma-Aldrich), 15\% FBS, 1\% detoxified BSA (StemCell Technologies), $200 \mu \mathrm{g} / \mathrm{mL}$ holotransferrin (SigmaAldrich), $10 \mathrm{mg} / \mathrm{mL}$ human insulin (Sigma-Aldrich), $2 \mathrm{mM}$ L-glutamine, $0.1 \mathrm{mM} \beta$ mercaptoethanol, and penicillin-streptomycin. After $48 \mathrm{~h}$, the medium was replaced by IMDM medium containing 20\% FBS, $2 \mathrm{mM} \mathrm{L}$-glutamine, $0.1 \mathrm{mM} \beta$-mercaptoethanol, and penicillin-streptomycin. $50 \%$ of the culture media was replaced after $48 \mathrm{~h}$ and cell density was maintained at $0.5 \times 10^{6} / \mathrm{mL}$. Total culture period for the assay was 6 days. Recombinant mouse IL-22 (PeproTech/Cell Signaling) was used where indicated. RII-RIV populations were gated as shown in Extended Data Fig. 2a.

\section{Proteomic profiling}

Proteomic profiling of sort-purified erythroid progenitors was performed as described elsewhere ${ }^{58}$. Briefly, cells were captured in collection microreactors and stored at $-80{ }^{\circ} \mathrm{C}$. 
Cell lysis was performed by adding $10 \mu \mathrm{L}$ of $8 \mathrm{M}$ urea, $10 \mathrm{mM}$ TCEP and $10 \mathrm{mM}$ iodoacetamide in $50 \mathrm{mM}$ ammonium bicarbonate $(\mathrm{ABC})$ to the cell pellet of $1 \times 10^{6}$ erythroid progenitors and incubatedat room temperature for $30 \mathrm{~min}$, shaking in the dark. 50 $\mathrm{mM} \mathrm{ABC}$ was used to dilute the urea to less than $2 \mathrm{M}$ and the appropriate amount of trypsin for a 1:100 enzyme to substrate ratio was added and allowed to incubate at $37^{\circ} \mathrm{C}$ overnight. Once digestion is completed, the lysate is spun through the glass mesh directly onto a C18 Stage tip (Empore ${ }^{59}$ ) at $3500 \times g$ until the entire digest passes through the $\mathrm{C} 18$ resin. $75 \mu \mathrm{L}$ $0.1 \%$ formic acid (FA) is then used to ensure transfer of peptides to the $\mathrm{C} 18$ resin from the mesh while washing away the lysis buffer components. C18-bound peptides were immediately subjected to on-column TMT labeling.

On-column TMT Labeling - - Resin was conditioned with $50 \mu \mathrm{L}$ methanol $(\mathrm{MeOH})$, followed by $50 \mu \mathrm{L} 50 \%$ acetonitrile (ACN)/0.1\% FA, and equilibrated with $75 \mu \mathrm{L} 0.1 \%$ FA twice. The digest was loaded by spinning at $3500 \times g$ until the entire digest passed through. One $\mu \mathrm{L}$ of TMT reagent in $100 \%$ ACN was added to $100 \mu \mathrm{L}$ freshly made HEPES, $\mathrm{pH} 8$, and passed over the $\mathrm{C} 18$ resin at $350 \times g$ until the entire solution passed through. The HEPES and residual TMT was washed away with two applications of $75 \mu \mathrm{L} 0.1 \%$ FA and peptides were eluted with $50 \mu \mathrm{L} 50 \% \mathrm{ACN} / 0.1 \%$ FA followed by a second elution with $50 \%$ $\mathrm{ACN} / 20 \mathrm{mM}$ ammonium formate $\left(\mathrm{NH}_{4} \mathrm{HCO}_{2}\right), \mathrm{pH} 10$. Peptide concentrations were estimated using an absorbance reading at $280 \mathrm{~nm}$ and checking of label efficiency was performed on 1/20th of the elution. After using 1/20th of the elution to test for labeling efficiency, the samples are mixed before fractionation and analysis.

Stage tip bSDB Fractionation - - 200 $\mu \mathrm{L}$ pipette tips were packed with two punches of sulfonated divinylbenzene (SDB-RPS, Empore) with a 16-gauge needle. After loading 20 $\mu \mathrm{g}$ peptides total, a pH switch was performed using $25 \mu \mathrm{L} 20 \mathrm{mM} \mathrm{NH}_{4} \mathrm{HCO}_{2}, \mathrm{pH} 10$, and was considered part of fraction one. Then, step fractionation was performed using ACN concentrations of 5, 7.5, 10, 12.5, 15, 17.5, 20, 25, 42, and 50\%. Each fraction was transferred to autosampler vials and dried via vacuum centrifugation and stored at $80{ }^{\circ} \mathrm{C}$ until analysis.

Data Acquisition --Chromatography was performed using a Proxeon UHPLC at a flow rate of $200 \mathrm{nl} / \mathrm{min}$. Peptides were separated at $50{ }^{\circ} \mathrm{C}$ using a $75 \mu \mathrm{m}$ i.d. PicoFrit (New Objective) column packed with $1.9 \mu \mathrm{m}$ AQ-C18 material (Dr. Maisch, Germany) to $20 \mathrm{~cm}$ in length over a $110 \mathrm{~min}$ run. The on-ine LC gradient went from 6\% B at $1 \mathrm{~min}$ to $30 \% \mathrm{~B}$ in 85 mins, followed by an increase to $60 \%$ B by minute 94 , then to $90 \%$ by $\min 95$, and finally to $50 \%$ B until the end of the run. Mass spectrometry was performed on a Thermo Scientific Lumos Tribrid mass spectrometer. After a precursor scan from 350 to $1800 \mathrm{~m} / \mathrm{z}$ at 60,000 resolution, the topmost intense multiply charged precursors in a 2 second window were selected for higher energy collisional dissociation (HCD) at a resolution of 50,000. Precursor isolation width was set to $0.7 \mathrm{~m} / \mathrm{z}$ and the maximum MS2 injection time was $110 \mathrm{msecs}$ for an automatic gain control of 6e4. Dynamic exclusion was set to $45 \mathrm{~s}$ and only charge states two to six were selected for MS2. Half of each fraction was injected for each data acquisition run. 
Data Processing --Data were searched all together with Spectrum Mill (Agilent) using the Uniprot Mouse database (28 Dec. 2017), containing common laboratory contaminants and 553 smORFs. A fixed modification of carbamidomethylation of cysteine and variable modifications of $\mathrm{N}$-terminal protein acetylation, oxidation of methionine, and TMT-11plex labels were searched. The enzyme specificity was set to trypsin and a maximum of three missed cleavages was used for searching. The maximum precursor-ion charge state was set to six. The MS1 and MS2 mass tolerance were set to $20 \mathrm{ppm}$. Peptide and protein FDRs were calculated to be less than $1 \%$ using a reverse, decoy database. Proteins were only reported if they were identified with at least two distinct peptides and a Spectrum Mill score protein level score $\sim 20$.

TMT11 reporter ion intensities in each MS/MS spectrum were corrected for isotopic impurities by the Spectrum Mill protein/peptide summary module using the afRICA correction method which implements determinant calculations according to Cramer's Rule and general correction factors obtained from the reagent manufacturer's certificate of analysis.

Differential Protein Abundance Analysis - - The median normalized, median absolute deviation- scale data set was subjected to a moderated F-test, followed by BenjaminiHochberg Procedure correcting for multiple hypothesis testing. We drew an arbitrary cutoff at adj. $\mathrm{p}$ val $<0.05$.

\section{RNA Sequencing (RNA-Seq)}

$\left.5000 \mathrm{IL}-22{ }^{+}\left(\mathrm{CD}^{+}{ }^{+} \mathrm{IL}-22 \text { (tdtomato }\right)^{+}\right)$cells were FACS sorted directly into TLC Buffer (Qiagen) with $1 \% \beta$-mercaptoethanol. For the preparation of libraries, cell lysates were thawed and RNA was purified with 2.2x RNAClean SPRI beads (Beckman Coulter Genomics) without final elution ${ }^{60}$. The RNA captured beads were air-dried and processed immediately for RNA secondary structure denaturation $\left(72{ }^{\circ} \mathrm{C}\right.$ for $\left.3 \mathrm{~min}\right)$ and cDNA synthesis. SMART-seq2 was performed on the resultant samples following the published protocol $^{61}$ with minor modifications in the reverse transcription (RT) step. A $15 \mu \mathrm{L}$ reaction mix was used for subsequent PCR and performed 10 cycles for cDNA amplification. The amplified cDNA from this reaction was purified with $0.8 \times$ Ampure SPRI beads (Beckman Coulter Genomics) and eluted in $21 \mu \mathrm{L}$ TE buffer. We used $0.2 \mathrm{ng}$ cDNA and one-eighth of the standard Illumina NexteraXT (Illumina FC-131-1096) reaction volume to perform both the tagmentation and PCR indexing steps. Uniquely indexed libraries were pooled and sequenced with NextSeq 500 high output V2 75 cycle kits (Illumina FC-404-2005) and $38 \times$ 38 paired-end reads on the NextSeq 500 instrument. Reads were aligned to the mouse mm10 transcriptome using Bowtie ${ }^{62}$, and expression abundance TPM estimates were obtained using RSEM ${ }^{63}$.

\section{Pathway analysis}

Gene set enrichment analysis (GSEA) was performed with Broad Institute's GSEA Software ${ }^{64}$. The 'IL-22_Signature' and 'Rps14_Increased' gene sets were created from the literature ${ }^{55,65}$ (Fig. 2c,f). Full lists of genes in the individual gene sets can be found in Supplementary Table 1. Other reference gene sets are available from MSigDB ${ }^{66}$. For GSEA 
analyses, mouse UniProt IDs were converted to their orthologous human gene symbols using MSigDB 7.1 CHIP file mappings. Pathway enrichment (Fig. 2e) was performed using Clarivate Analytics' MetaCore ${ }^{\mathrm{TM}}$ software ${ }^{67}$.

\section{Microarray data analysis}

Microarray data of $\mathrm{CD} 34^{+}$cells from healthy, del(5q), and non-del(5q) MDS subjects was obtained from a previously published study ${ }^{68}$ submitted in Gene Expression Omnibus ${ }^{69,70}$ accessible under GSE19429.

\section{Statistical tests}

Data are presented as mean \pm s.e.m unless otherwise indicated. Comparison of two groups was performed using paired or unpaired two-tailed $t$-test. For multiple group comparisons, analysis of variance (ANOVA) with Tukey's correction or Kruskal-Wallis test with Dunn's correction was depending on data requirements. Statistical analyses were performed using GraphPad Prism v8.0 (GraphPad Software Inc.). A $P$-value of less than 0.05 was considered significant.

\section{Reporting Summary}

Further information on research design is available in the Nature Research Reporting Summary linked to this article.

\section{Extended Data}

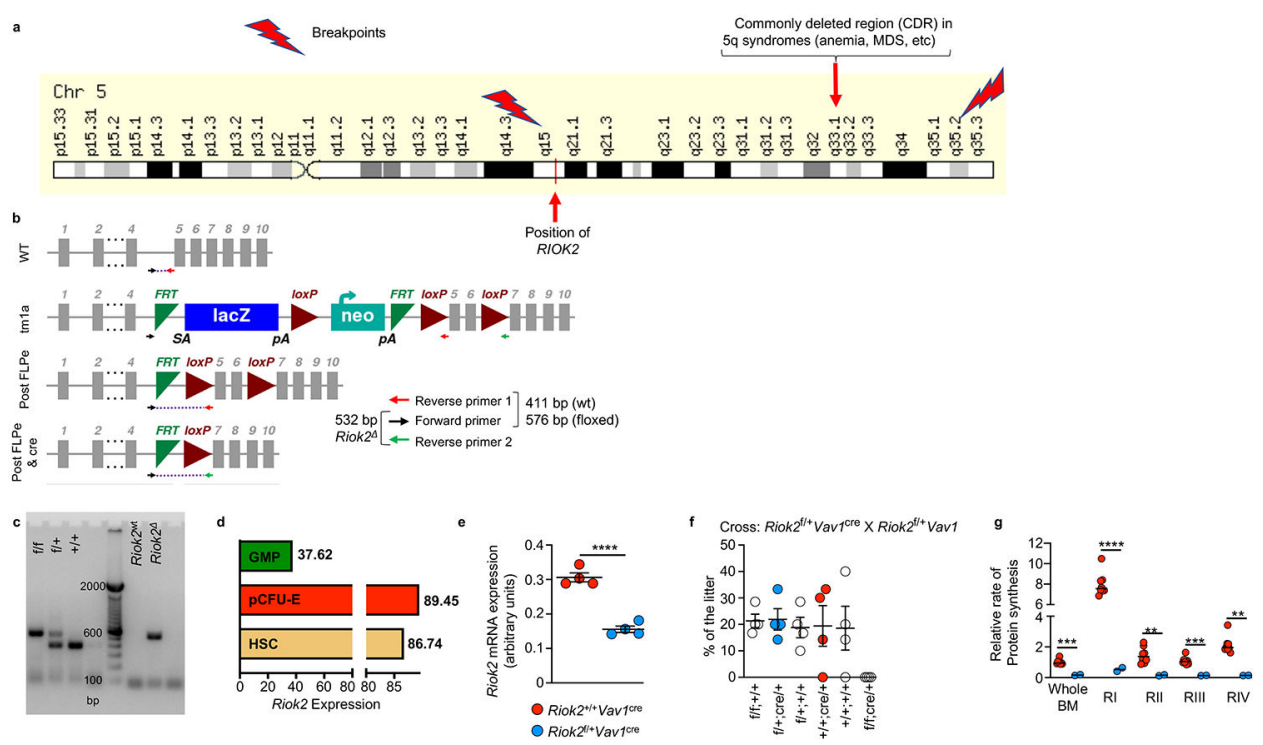

Extended Data Fig. 1. Localization and expression of Riok2.

(a) Location of RIOK2 gene on human chromosome 5. (b) Schematic representation of the Riok $2^{\mathrm{tm} 1 \mathrm{a}(\mathrm{KOMP}) \mathrm{Wtsi}}$ allele and generation of Riok2 floxed mice. (c) Agarose gel showing genotyping of Riok2 floxed mice. Riok $2^{4}$ indicates deletion of Riok2. No band expected in the Riok $2^{\mathrm{wt}}$ lane. (d) Expression of Riok2 mRNA in mouse BM cells. Modified from Gene Expression Commons. Numbers next to bars indicate expression level. (e) Riok2 mRNA 
expression by qRT-PCR in BM cells from Riok2 haploinsufficient mice and Vav ${ }^{\text {cre }}$ controls. $\mathrm{n}=5$ mice/group. (f) Frequency of the genotypes indicated on the $\mathrm{X}$-axis among 4 litters from 4 different breeding crosses of the genotypes mentioned. (g) In vivo protein synthesis rates in the indicated cell types from Riok2 haploinsufficient mice $(\mathrm{n}=2)$ and $\operatorname{Vav}{ }^{\text {cre }}$ controls $(\mathrm{n}=8)$. Unpaired two-tailed $t$-test (e), multiple unpaired two-tailed $t$-tests with Holm-Sidak method (g) used to calculate statistical significance. Data are shown as mean \pm s.e.m (e,f) or mean \pm s.d. (g) and are representative of two (e, g) or four (c, f) independent experiments. $* * \mathrm{p}<0.01, * * * \mathrm{p}<0.001, * * * * \mathrm{p}<0.0001$.

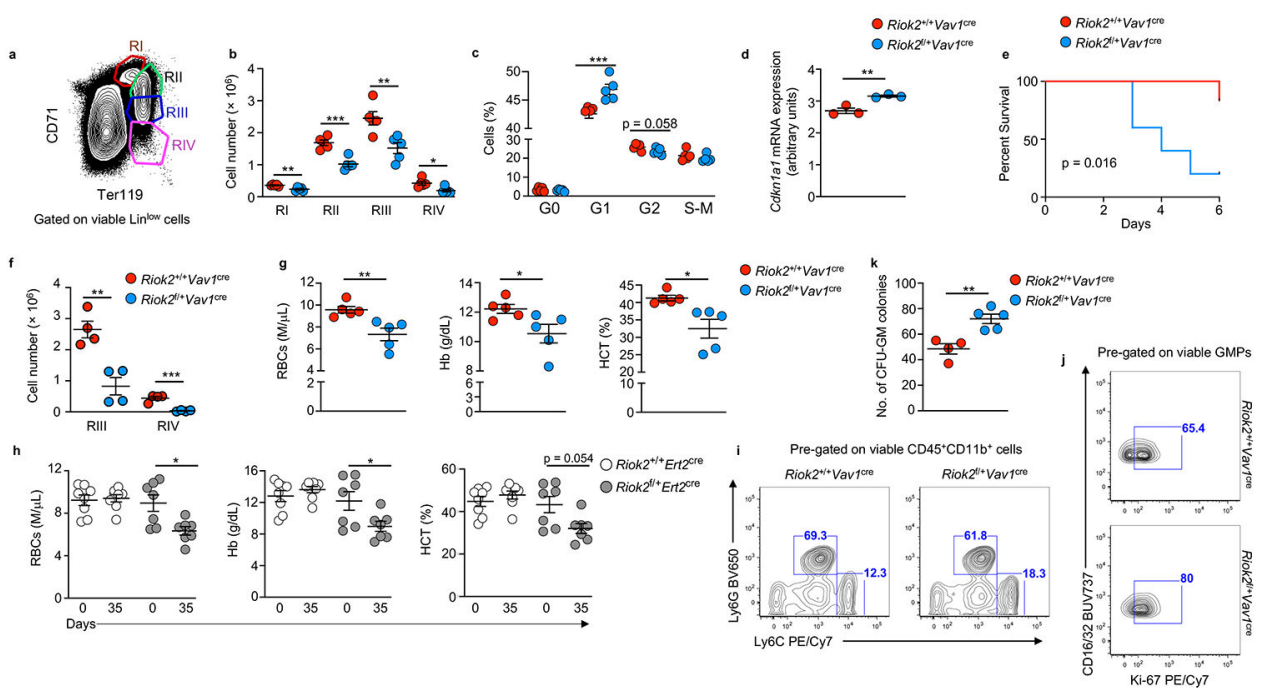

Extended Data Fig. 2. Riok2 haploinsufficient mice display anemia and myeloproliferation.

(a) Gating strategy used for the identification of erythroid progenitor/ precursor cells in the BM. (b) Number of erythroid progenitor populations among viable BM cells in Riok $2^{\text {fl+ }}$ Vavl $^{\text {cre }}$ mice and Riok $2^{+/+} \operatorname{VaV}{ }^{\text {cre }}$ controls. n=5/group. (c) Cell cycle analysis of erythroid progenitor/ precursor cells from Riok2 haploinsufficient mice in comparison to Vav ${ }^{\text {cre }}$ controls. $\mathrm{n}=5$ mice/group. (d) Cdkn1a mRNA expression by qRT-PCR in erythroid progenitors from Riok 2 haploinsufficient mice and Vav ${ }^{\text {cre }}$ controls. $\mathrm{n}=3$ mice/group. (e) Kaplan-Meier survival curve for Riok2 haploinsufficient mice and $\operatorname{Vav}^{\text {cre }}$ controls subjected to lethal dose of PhZ. (f) Number of RIII and RIV erythroid precursor populations among viable BM cells in Riok $2^{\text {f/+ } V a v 1}$ cre $^{\text {re }}$ mice and Riok $2^{+/+} \operatorname{Vav}^{\text {cre }}$ controls day 6 after $\mathrm{PhZ}$ treatment. n=4/group. (g) PB RBC numbers, $\mathrm{Hb}$, and HCT in mice transplanted with either Riok2 haploinsufficient mice or Vav ${ }^{\text {cre }}$ BM cells. $\mathrm{n}=5$ mice/group. (h) PB RBC numbers, $\mathrm{Hb}$, and HCT in mice with tamoxifen-inducible deletion of Riok2. Tamoxifen administered on days $3-7 . \mathrm{n}=8$ and 7 for Riok $2^{+/+}$Ert $2^{\text {ree }}$ and $R$ iok $2^{\mathrm{f} /+}$ Ert 2 re mice, respectively. (i) Representative flow cytometry plots showing frequency of monocytes $\left(\mathrm{CD} 11 \mathrm{~b}^{+} \mathrm{Ly}_{6 \mathrm{G}}{ }^{-} \mathrm{Ly} 6 \mathrm{C}^{\mathrm{hi}}\right)$ and neutrophils $\left(\mathrm{CD} 11 \mathrm{~b}^{+} \mathrm{Ly}_{6 \mathrm{G}}\right)$ in the PB of Riok $2^{\mathrm{f} /+} \operatorname{Vav}^{\text {cre }}$ and Riok2 ${ }^{+/+} \operatorname{Vav}^{1}{ }^{\text {re }}$ mice. (j) Representative flow cytometry plots showing Ki-67 ${ }^{+}$GMPs in the

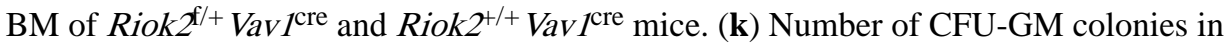
MethoCult from Lin $^{-} \mathrm{Sca}-1^{+} \mathrm{c}-\mathrm{kit}^{+} \mathrm{BM}$ cells from Riok $2^{\mathrm{f} /+} \operatorname{Vav}_{1} 1^{\mathrm{cre}}$ mice $(\mathrm{n}=5)$ and Riok $^{+/+} \operatorname{Vav}^{\text {cre }}$ controls $(\mathrm{n}=4)$ after a 7-day culture period. n=4-5/group. Multiple unpaired two-tailed $t$-tests with Holm-Sidak method (b, c), unpaired two-tailed $t$-test (d, f, g, k), log- 
rank test (e), and 2-way ANOVA with Sidak's correction for multiple comparisons (h) used to calculate statistical significance. Data are shown as mean \pm s.e.m and are representative of two (b to k) independent experiments. $* \mathrm{p}<0.05, * * \mathrm{p}<0.01, * * * \mathrm{p}<0.001$.

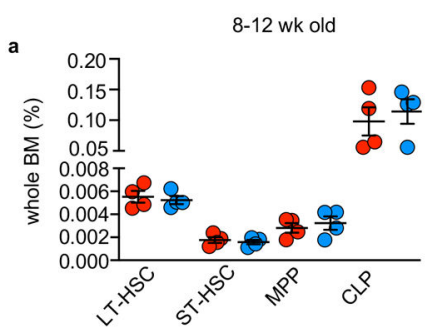

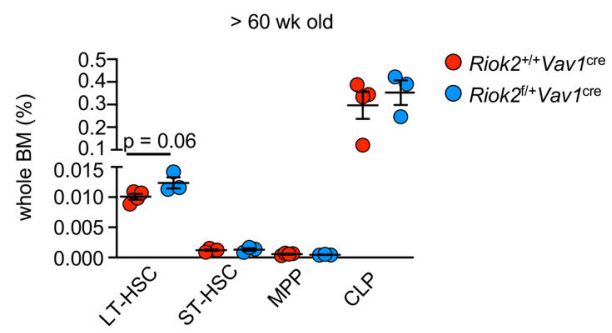

b
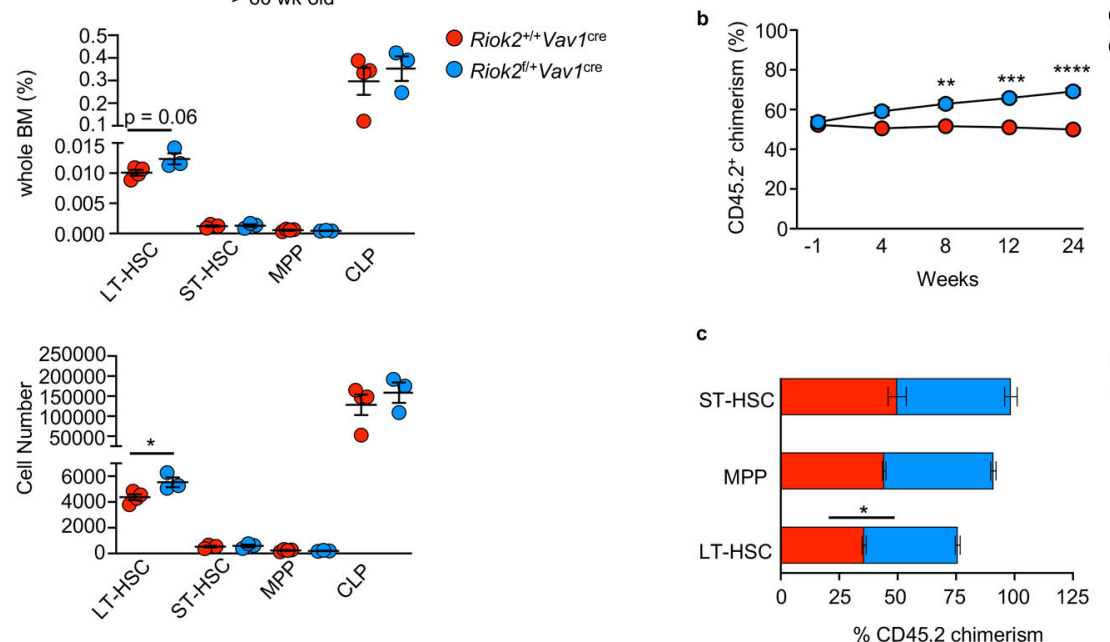

Riok $2^{+++}$Ert2 cre

Riok ${ }^{\mathrm{ft}+\mathrm{E}} \mathrm{Ert2}$ cre

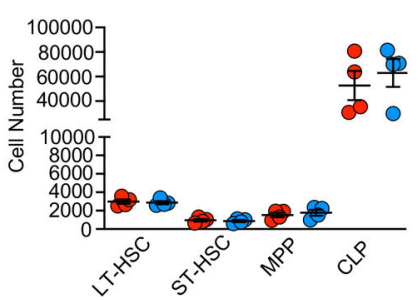

Riok2 ${ }^{+/+} E r t 2^{\text {cre }}$

Riok $2^{\mathrm{f} /+}$ Ert2cre

Extended Data Fig. 3. Riok2 haploinsufficiency alters early hematopoietic progenitors in an agedependent fashion.

(a) Frequency and number of indicated cell types in the bone marrow of Riok $2^{\mathrm{fl+}} \operatorname{VaV}^{\mathrm{cre}}$ and Riok $2^{+/+} \operatorname{Vav}^{\text {cre }}$ mice. $\mathrm{n}=4$ /group. LT-HSC $=$ long term hematopoietic stem cells, ST-HSC $=$ short term hematopoietic stem cells, $\mathrm{MPP}=$ multipotent progenitors, $\mathrm{CLP}=$ common lymphoid progenitors. (b) \% CD45.2 (donor) chimerism in PB from competitive BM transplant with CD45.1 recipient cells. Time point ' -1 ' reflects first bleeding 4 weeks after transplantation and one day before tamoxifen induced deletion of Riok2. Donor (CD45.2) chimerism of the HSC compartment in the BM of competitive transplantation experiments. $\mathrm{n}$ $=5 /$ group . (c) Frequency of donor $\left(\mathrm{CD} 45.2^{+}\right)$early hematopoietic progenitors 24 weeks after tamoxifen treatment in a competitive transplantation assay as described in (b). $\mathrm{n}=5$ and

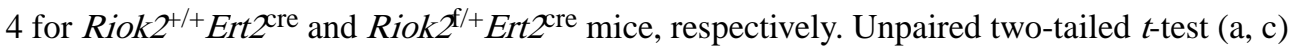
and 2-way ANOVA with Sidak's multiple comparison test (b) used to calculate statistical significance. Data are shown as mean \pm s.e.m and are representative of two (a-c) independent experiments. ${ }^{*} \mathrm{p}<0.05, * * \mathrm{p}<0.01, * * * \mathrm{p}<0.001, * * * * \mathrm{p}<0.0001$. 

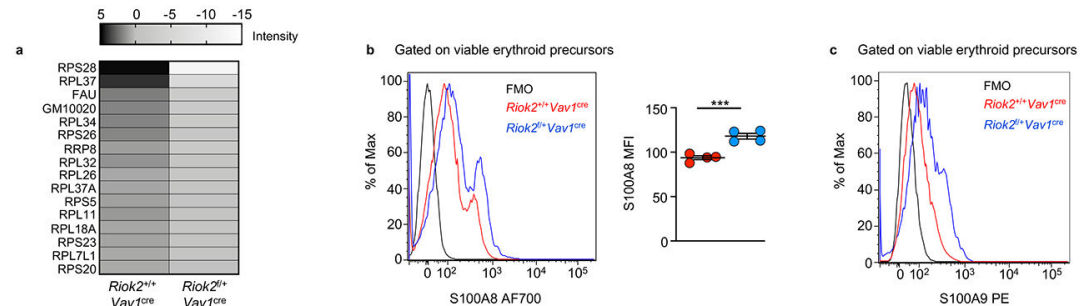

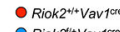
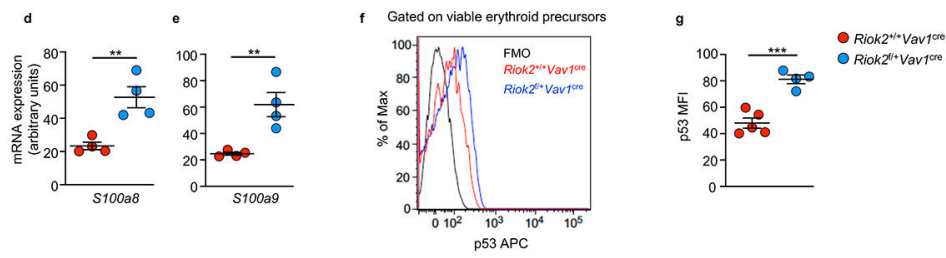

Extended Data Fig. 4. Riok2 haploinsufficient erythroid precursors express increased S100 proteins.

(a) Expression of ribosomal proteins quantified by proteomics in $\operatorname{Riok}^{\mathrm{f} /+} \mathrm{Vav}^{\mathrm{cre}}$ and Riok $^{+/+}$Vav $^{\text {cre }}$ erythroid precursors. S100A8 (b) and S100A9 (c) expression assessed by flow cytometry in BM erythroid precursors from Riok $2^{\mathrm{f} /+} \operatorname{Vav}^{\mathrm{cre}}$ and $R$ iok $2^{+/+}$Vav $^{\mathrm{cre}}$ mice. n=4mice/group. (d, e) $S 100 a 8$ and $S 100 a 9$ mRNA expression in erythroid precursors isolated from $\operatorname{Riok}^{\mathrm{f} /+} \operatorname{Vav}^{\mathrm{cre}}$ and Riok $^{+/+}$Vav $^{\text {cre }}$ mice. $\mathrm{n}=4$ mice/group. (f) p53 expression assessed by flow cytometry in BM erythroid precursors from Riok $2^{f /+}$ Vav $^{\text {cre }}$ and Riok $2^{+/+}$Vav $^{\text {cre }}$ mice. (g) Graphical representation of data shown in (e). $\mathrm{n}=5$ mice/group.

Data are shown as mean \pm s.e.m and are representative of two ( $b$ to $g$ ) independent experiments. Unpaired two-tailed $t$-test ( $b$ to $\mathrm{g}$ ) used to calculate statistical significance. $* * \mathrm{p}$ $<0.01, * * * \mathrm{p}<0.001, * * * * \mathrm{p}<0.0001$.
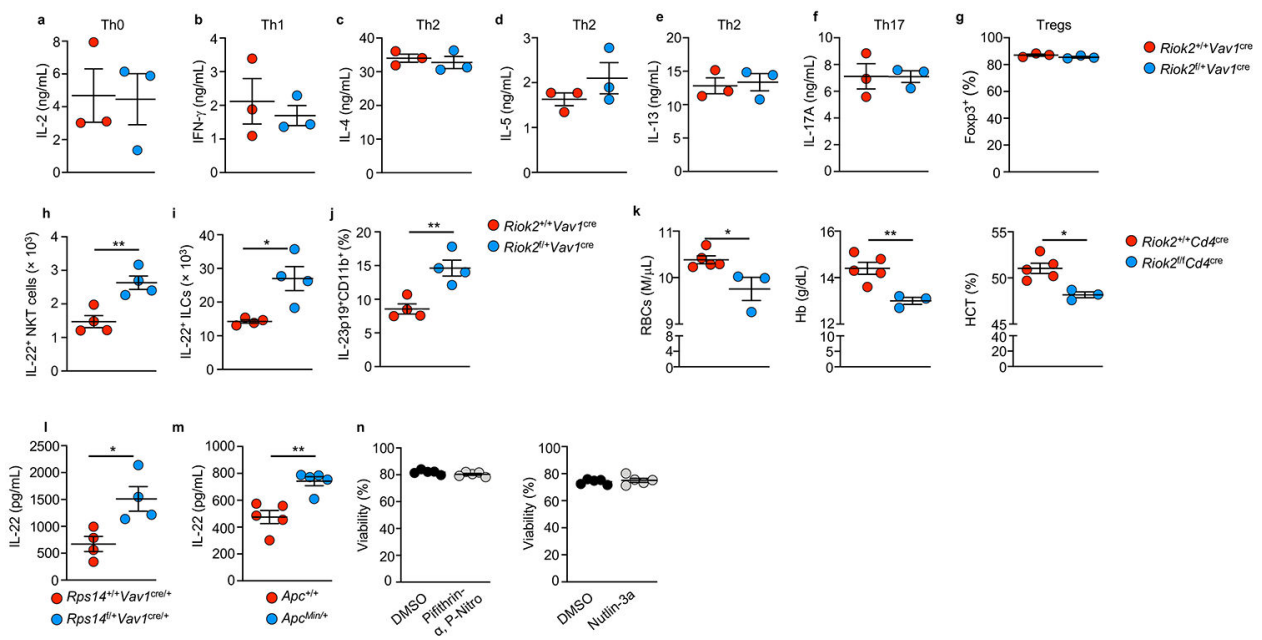

Extended Data Fig. 5. Expression of lineage-associated $T$ cell cytokines is comparable between Riok2 haploinsufficient and sufficient $T$ cells.

a-g, Concentration of IL-2 (a), IFN- $\gamma$ (b), IL-4 (c), IL-5 (d), IL-13 (e), IL-17A (f) and frequency of Foxp $3^{+}$cells $(\mathbf{g})$ from in vitro polarized $\mathrm{T}$ cells of the indicated genotypes. $\mathrm{n}=3$ mice/group. (h-i) Number of IL-22+ NKT cells (H) and ILCs (I) in the spleens of Riok $2^{f l+}$ Vav $^{\text {cre }}$ mice and Riok $2^{+/+}$Vav $^{\text {cre }}$ controls (n=4/group). (j) Frequency of 
IL_23p $19^{+}$DCs in Riok $2^{f+}$ Vav $1^{\text {cre }}$ mice and Riok $2^{+/+}$VaV $^{\text {cre }}$ controls. $\mathrm{n}=4$ mice/group. (k) PB RBC numbers, $\mathrm{Hb}$, and HCT in $\operatorname{Riok}^{2 / / f} C d 4^{\text {re }}$ mice (n=3) in comparison to Riok $2^{+/+} C d 4^{\text {re }}$ controls ( $\left.=5\right)$. (l) Secreted IL-22 from in vitro polarized $\mathrm{T}_{\mathrm{H}} 22$ cells from Rps14 haploinsufficient mice and Vav $1^{\text {cre }}$ controls. $\mathrm{n}=4$ mice/group. (m) Secreted IL-22 from in vitro polarized $\mathrm{T}_{\mathrm{H}} 22$ cells from $A p c^{\mathrm{Min}}$ mice and littermate controls. $\mathrm{n}=4$ mice/ group. (n) Viable cells (expressed as percentage of total cells in culture) for the indicated treatments assessed by flow cytometry. $n=5$ mice/group. Data are shown as mean \pm s.e.m and are representative of two (a to $\mathrm{n}$ ) independent experiments. Unpaired two-tailed $t$-test (a to $\mathrm{n})$ used to calculate statistical significance. $* \mathrm{p}<0.05, * * \mathrm{p}<0.01$.
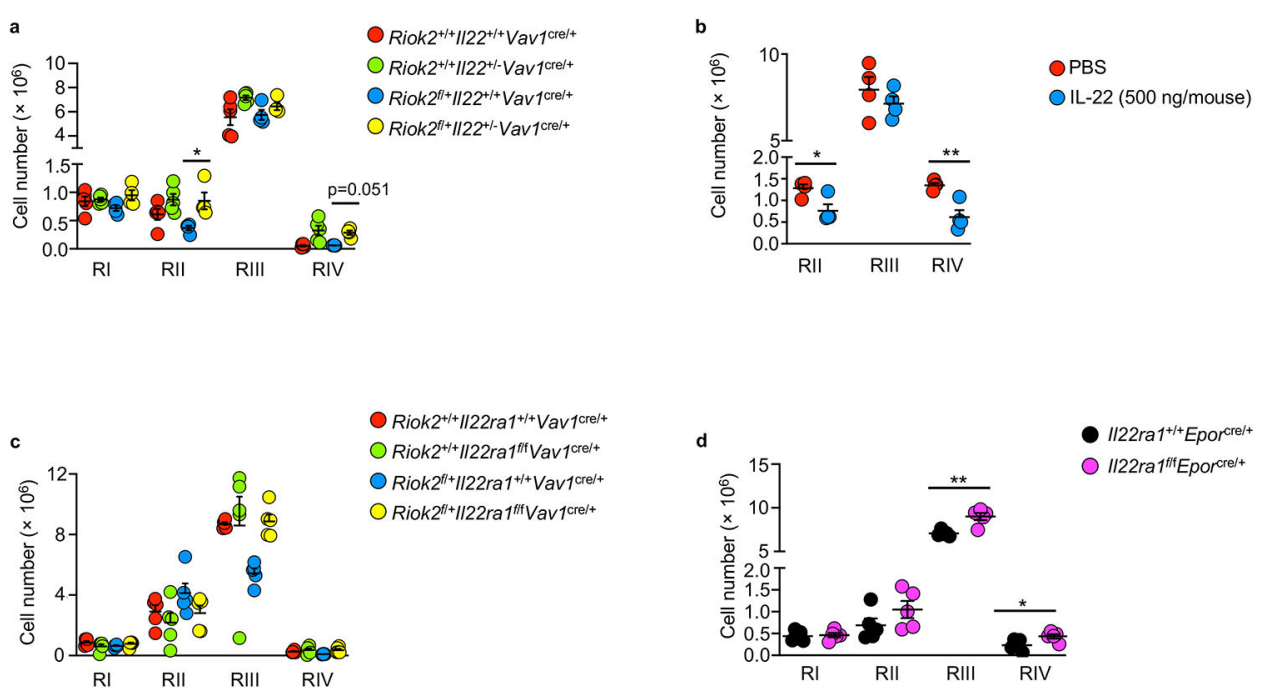

Extended Data Fig. 6. Neutralization of IL-22 signaling increases number of erythroid precursors.

a-d, Number of RI-RIV erythroid populations among viable BM cells in the indicated strains undergoing PhZ-induced stress erythropoiesis. For (a), $\mathrm{n}=5,5,4$, and 4 for

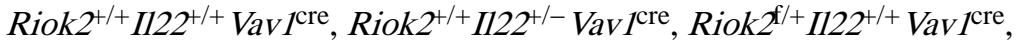
Riok $^{2 / /+} I I 22^{+/-}$Vav $^{\text {cre }}$, respectively. For (d), n=5/group. Data are shown as mean \pm s.e.m and are representative of three (a, c) or two (b, d) independent experiments. 1-way ANOVA with Tukey's correction $(\mathrm{a}, \mathrm{c})$ or unpaired two-tailed $t$-test $(\mathrm{b}, \mathrm{d})$ used to calculate statistical significance. $* \mathrm{p}<0.05, * * \mathrm{p}<0.01$.
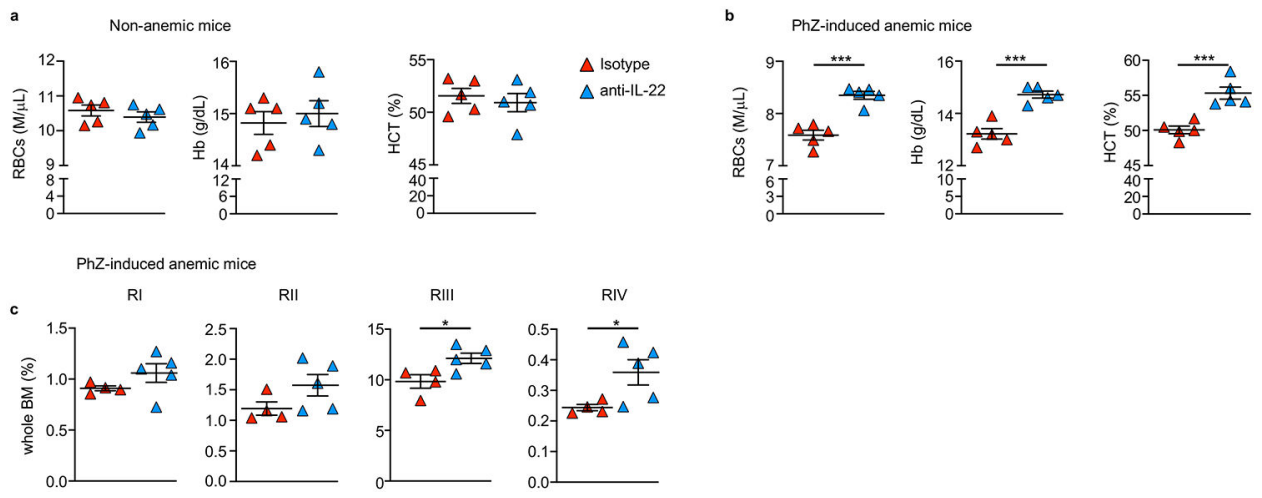
Extended Data Fig. 7. IL-22 neutralization alleviates anemia in wt mice undergoing PhZ-induced stress erythropoiesis.

(a) PB RBC numbers, Hb, and HCT in naïve wt C57BL/6J mice treated with isotype control (Rat IgG2ax, $50 \mathrm{mg} / \mathrm{mouse}$ ) or anti-IL-22 antibody (50 mg/mouse). $\mathrm{n}=5 \mathrm{mice} / \mathrm{group}$. (b) PB RBC numbers, Hb, and HCT in wt C57BL/6J mice undergoing PhZ-induced stress erythropoiesis treated with isotype control or anti-IL-22 antibody. $n=5$ mice/group. (c) Percentage of RI-RIV erythroid precursors in the BM of mice treated as in (b). n=4 and 5 for II22 $\mathrm{raI}^{+/+}$Epor $^{\mathrm{cre}}$ and II22ral ${ }^{\mathrm{f} / \mathrm{f}}$ Epor $^{\mathrm{cre}}$ mice, respectively. Data are shown as mean \pm s.e.m and are representative of three $(a, b)$ or two $(c)$ independent experiments. Unpaired twotailed $t$-test (a to c) used to calculate statistical significance. $* \mathrm{p}<0.05, * * * \mathrm{p}<0.001$.

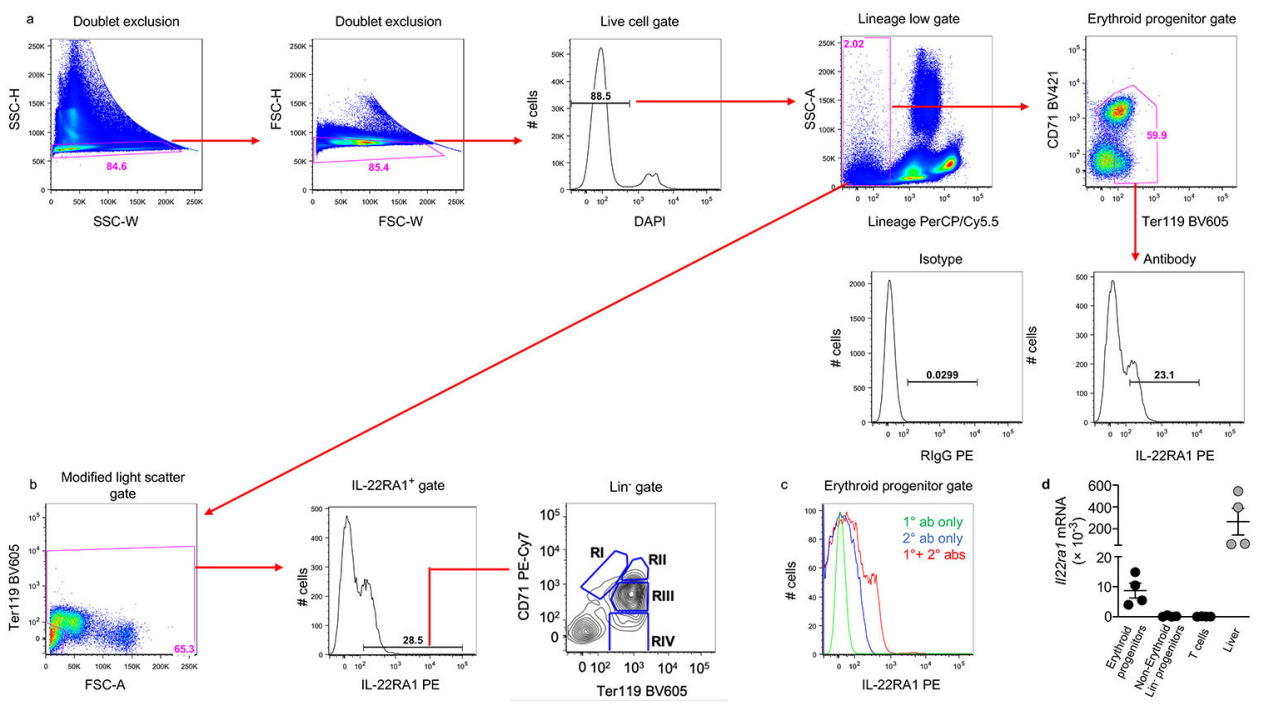

Extended Data Fig. 8. Erythroid precursors express IL-22RA1.

(a) Gating strategy employed for assessing IL-22RA1 expression on erythroid precursors.

(b) Gating strategy to show that majority of IL-22RA1 ${ }^{+}$cells in the mouse BM are erythroid precursors. (c) IL-22RA1 expression on erythroid precursors assessed using flow cytometry and a second antibody targeting a different epitope of IL-22RA1. (d) II22ra1 mRNA expression in the indicated cell types assessed by qRT-PCR. T cells and liver represent negative and positive controls, respectively. $n=4$ mice/group. Data are shown as mean \pm s.e.m (d) and are representative of three (a to c) or two (d) independent experiments. 


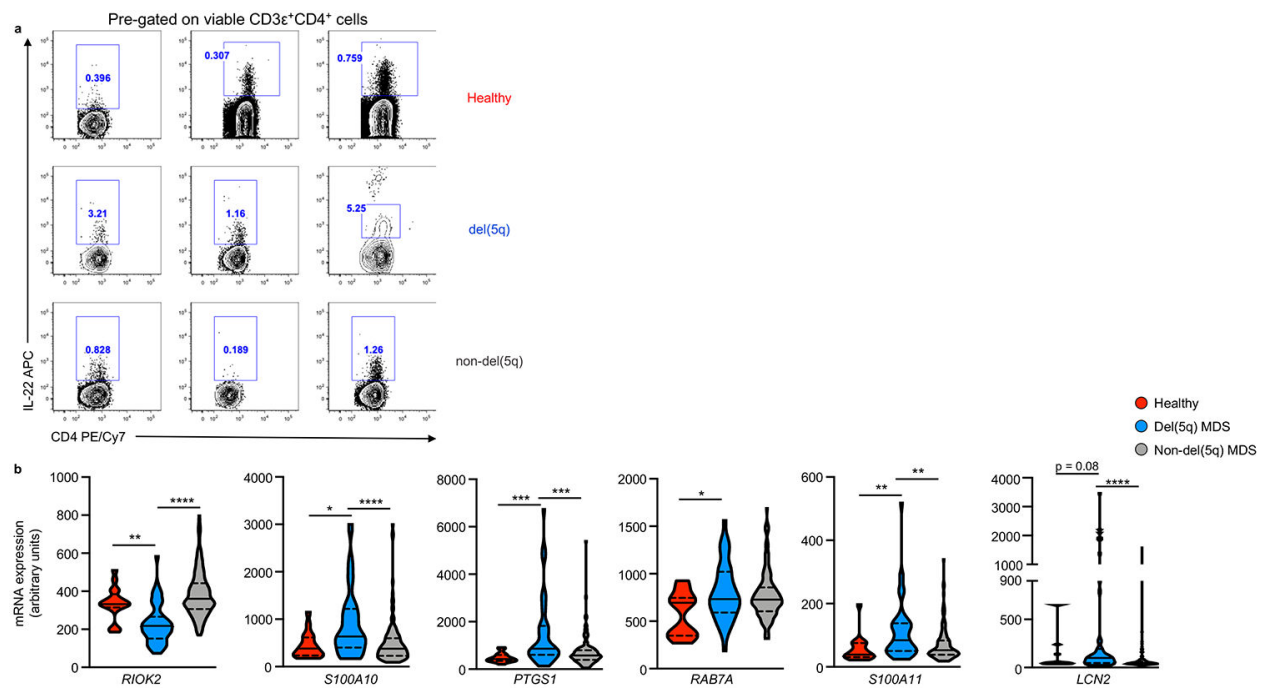

Extended Data Fig. 9. Increased IL-22 and its signature genes in del(5q) MDS subjects.

(a) Representative flow cytometry plots showing frequency of $\mathrm{CD} 4^{+} \mathrm{IL}-22^{+}$cells among total PBMCs in the peripheral blood of MDS patients and healthy subjects. Pre-gated on viable $\mathrm{CD} 3 \varepsilon^{+} \mathrm{CD} 4^{+}$cells. Cumulative data shown in Figure 4e. (b) Expression of indicated IL-22 signature genes in $\mathrm{CD}_{3} 4^{+}$cells from healthy controls and $\operatorname{del}(5 \mathrm{q})$ and non-del(5q) MDS patients. $\mathrm{n}=17,47$, and 136 for healthy, $\operatorname{del}(5 \mathrm{q}) \mathrm{MDS}$, and non-del(5q) MDS, respectively. Kruskal-Wallis test with Dunn's correction for multiple comparisons (b) used to calculate statistical significance $* \mathrm{p}<0.05, * * \mathrm{p}<0.01, * * * \mathrm{p}<0.001, * * * * \mathrm{p}<0.0001$. Solid lines represent median and dashed lines represent quartiles (b).

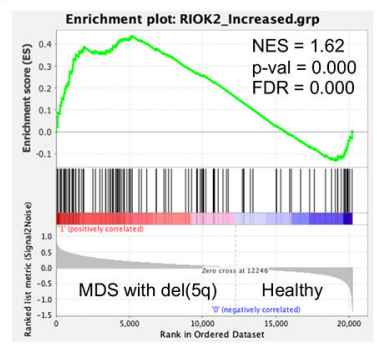

b

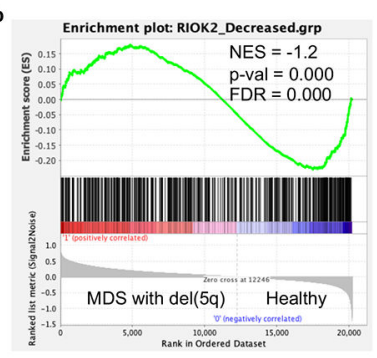

c

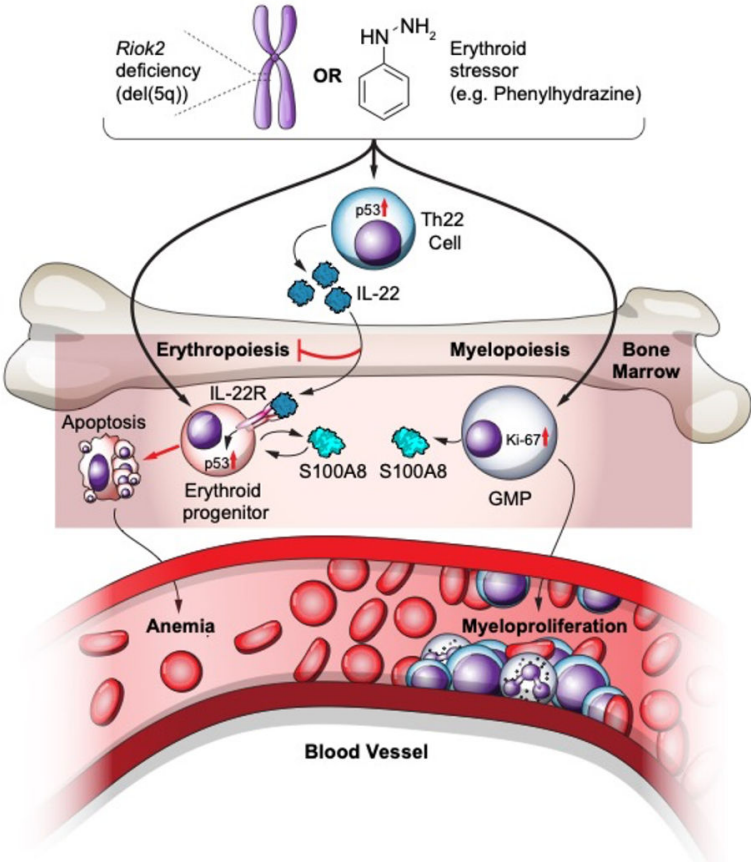


Extended Data Fig. 10. Riok2 haploinsufficiency recapitulates del(5q) MDS transcriptional changes.

(a to b) GSEA enrichment plots comparing proteins up-regulated (a) and down-regulated (b) upon Riok2 haploinsufficiency to the transcriptional changes seen in $\operatorname{del}(5 q)$ MDS. (c) Schematic of mechanism underlying Riok 2 haploinsufficiency-induced, IL-22 -induced anemia.

\section{Supplementary Material}

Refer to Web version on PubMed Central for supplementary material.

\section{Acknowledgements}

We thank R. Caspi (National Eye Institute, US National Institutes of Health (NIH)) and Genentech for providing II22 knockout mice; B. L. Ebert (Dana-Farber Cancer Institute) for providing Rps14 floxed mice; R. Locksley (University of California, San Francisco) for providing Catch22 mice; and U. Klingmüller (Deutsches Krebsforschungszentrum (DFKZ), Germany) for providing Epor-cre mice. We also thank the Animal Resources Facility (ARF), The Ted and Eileen Pasquarello Tissue Bank in Hematologic Malignancies and flow cytometry core facility at DFCI for their valuable technical assistance. We thank E. Smith for assistance with creating the graphical illustration. We thank P. Májek (Ústav hematologie a krevní transfuse, ÚHKT) for providing plasma proteomic profiling data of healthy subjects and MDS patients.

Funding: This work was supported by a Discovery Research Grant from the Edward P. Evans Foundation (L.H.G.) and institutional funding from Dana-Farber Cancer Institute (L.H.G). D.P.S. is supported by the Edward P. Evans Foundation and by NIH Leukemia SPORE 1P50CA206963 and 2P01CA066996. This work was supported in part by grants from the National Cancer Institute (NCI) Clinical Proteomic Tumor Analysis Consortium grants NIH/NCI U24-CA210986 and NIH/NCI U01 CA214125 (to S.A.C.).

\section{Data availability}

The original mass spectra may be downloaded from MassIVE (http:IImassive.ucsd.edu), MSV000085287. The data are directly accessible via ftp://massive.ucsd.edu/ MSV000085287/. Raw RNA-Seq data is accessible via Gene Expression Omnibus (GEO) under the accession code GSE165467.

Source data for all applicable figures (Main and Extended) will be provided with the paper. The remaining data supporting the findings of this study are available from the corresponding authors upon reasonable request. Materials will be provided with material transfer agreements (MTA) as appropriate.

\section{References}

1. Giagounidis AA, Germing U \& Aul C Biological and prognostic significance of chromosome $5 \mathrm{q}$ deletions in myeloid malignancies. Clin. Cancer Res 12, 5-10 (2006). [PubMed: 16397017]

2. Haase D et al. New insights into the prognostic impact of the karyotype in MDS and correlation with subtypes: evidence from a core dataset of 2124 patients. Blood 110, 4385-4395 (2007). [PubMed: 17726160]

3. Hofmann WK, Lubbert M, Hoelzer D \& Phillip Koeffler H Myelodysplastic syndromes. Hematol. J 5, 1-8 (2004). [PubMed: 14745424]

4. Sole $\mathrm{F}$ et al. Incidence, characterization and prognostic significance of chromosomal abnormalities in 640 patients with primary myelodysplastic syndromes. Grupo Cooperativo Espanol de Citogenetica Hematologica. Br. J. Haematol 108, 346-356 (2000). [PubMed: 10691865]

5. Dutt $\mathrm{S}$ et al. Haploinsufficiency for ribosomal protein genes causes selective activation of p53 in human erythroid progenitor cells. Blood 117, 2567-2576 (2011). [PubMed: 21068437] 
6. Ebert BL et al. Identification of RPS14 as a 5q- syndrome gene by RNA interference screen. Nature 451, 335-339 (2008). [PubMed: 18202658]

7. Kumar MS et al. Coordinate loss of a microRNA and protein-coding gene cooperate in the pathogenesis of 5q- syndrome. Blood 118, 4666-4673 (2011). [PubMed: 21873545]

8. Ribezzo F et al. Rps14, Csnk1a1 and miRNA145/miRNA146a deficiency cooperate in the clinical phenotype and activation of the innate immune system in the 5q- syndrome. Leukemia, (2019).

9. Schneider RK et al. Role of casein kinase $1 \mathrm{~A} 1$ in the biology and targeted therapy of del(5q) MDS. Cancer Cell 26, 509-520 (2014). [PubMed: 25242043]

10. Schneider RK et al. Rps14 haploinsufficiency causes a block in erythroid differentiation mediated by S100A8 and S100A9. Nat. Med 22, 288-297 (2016). [PubMed: 26878232]

11. Ferreira-Cerca $S$ et al. ATPase-dependent role of the atypical kinase Rio2 on the evolving pre-40S ribosomal subunit. Nat. Struct. Mol. Biol 19, 1316-1323 (2012). [PubMed: 23104056]

12. Royer-Pokora B et al. Delineation by molecular cytogenetics of $5 q$ deletion breakpoints in myelodyplastic syndromes and acute myeloid leukemia. Cancer Genet. Cytogenet 167, 66-69 (2006). [PubMed: 16682289]

13. Tang $\mathrm{G}$ et al. Isolated del(5q) in Patients Following Therapies for Various Malignancies May Not All Be Clinically Significant. Am. J. Clin. Pathol 144, 78-86 (2015). [PubMed: 26071464]

14. Boultwood $\mathrm{J}$ et al. Narrowing and genomic annotation of the commonly deleted region of the $5 \mathrm{q}-$ syndrome. Blood 99, 4638-4641 (2002). [PubMed: 12036901]

15. Lai $\mathrm{F}$ et al. Transcript map and comparative analysis of the $1.5-\mathrm{Mb}$ commonly deleted segment of human 5q31 in malignant myeloid diseases with a del(5q). Genomics 71, 235-245 (2001). [PubMed: 11161817]

16. Zemp I et al. Distinct cytoplasmic maturation steps of $40 \mathrm{~S}$ ribosomal subunit precursors require hRio2. J. Cell Biol 185, 1167-1180 (2009). [PubMed: 19564402]

17. Muto $\mathrm{T}$ et al. Adaptive response to inflammation contributes to sustained myelopoiesis and confers a competitive advantage in myelodysplastic syndrome HSCs. Nat. Immunol 21, 535-545 (2020). [PubMed: 32313245]

18. Smith MA et al. U2AF1 mutations induce oncogenic IRAK4 isoforms and activate innate immune pathways in myeloid malignancies. Nat. Cell Biol 21, 640-650 (2019). [PubMed: 31011167]

19. Starczynowski DT \& Karsan A Innate immune signaling in the myelodysplastic syndromes. Hematol. Oncol. Clin. North Am 24, 343-359 (2010). [PubMed: 20359630]

20. Yang L, Qian Y, Eksioglu E, Epling-Burnette PK \& Wei S The inflammatory microenvironment in MDS. Cell. Mol. Life Sci 72, 1959-1966 (2015). [PubMed: 25662443]

21. Allampallam K et al. Measurement of mRNA expression for a variety of cytokines and its receptors in bone marrows of patients with myelodysplastic syndromes. Anticancer Res. 19, 53235328 (1999). [PubMed: 10697556]

22. Schipperus MR et al. Interleukin-6 and interleukin-1 enhancement of GM-CSF-dependent proliferation of haematopoietic progenitor cells in myelodysplastic syndromes. Br. J. Haematol 77, 515-522 (1991). [PubMed: 2025577]

23. Shao LL et al. Th22 cells as well as Th17 cells expand differentially in patients with early-stage and late-stage myelodysplastic syndrome. PLoS One 7, e51339 (2012). [PubMed: 23236476]

24. Verhoef GE et al. Measurement of serum cytokine levels in patients with myelodysplastic syndromes. Leukemia 6, 1268-1272 (1992). [PubMed: 1280751]

25. Starczynowski DT \& Karsan A Deregulation of innate immune signaling in myelodysplastic syndromes is associated with deletion of chromosome arm 5q. Cell Cycle 9, 855-856 (2010). [PubMed: 20160505]

26. Means RT Jr. Pathogenesis of the anemia of chronic disease: a cytokine-mediated anemia. Stem Cells 13, 32-37 (1995). [PubMed: 7719246]

27. Song $\mathrm{M}$ et al. IRE1alpha-XBP1 controls $\mathrm{T}$ cell function in ovarian cancer by regulating mitochondrial activity. Nature 562, 423-428 (2018). [PubMed: 30305738]

28. Seita J et al. Gene Expression Commons: an open platform for absolute gene expression profiling. PLoS One 7, e40321 (2012). [PubMed: 22815738] 
29. Khajuria RK et al. Ribosome Levels Selectively Regulate Translation and Lineage Commitment in Human Hematopoiesis. Cell 173, 90-103 e119 (2018). [PubMed: 29551269]

30. Myers SA et al. Streamlined Protocol for Deep Proteomic Profiling of FAC-sorted Cells and Its Application to Freshly Isolated Murine Immune Cells. Mol. Cell. Proteomics 18, 995-1009 (2019). [PubMed: 30792265]

31. Su LK et al. Multiple intestinal neoplasia caused by a mutation in the murine homolog of the APC gene. Science 256, 668-670 (1992). [PubMed: 1350108]

32. Gronke $\mathrm{K}$ et al. Interleukin-22 protects intestinal stem cells against genotoxic stress. Nature 566, 249-253 (2019). [PubMed: 30700914]

33. Kotenko SV et al. Identification of the functional interleukin-22 (IL-22) receptor complex: the IL-10R2 chain (IL-10Rbeta) is a common chain of both the IL-10 and IL-22 (IL-10-related T cellderived inducible factor, IL-TIF) receptor complexes. J. Biol. Chem 276, 2725-2732 (2001). [PubMed: 11035029]

34. Kdoqi \& National Kidney, F. KDOQI Clinical Practice Guidelines and Clinical Practice Recommendations for Anemia in Chronic Kidney Disease. Am. J. Kidney Dis 47, S11-145 (2006). [PubMed: 16678659]

35. Maciejewski JP et al. A pilot study of the recombinant soluble human tumour necrosis factor receptor (p75)-Fc fusion protein in patients with myelodysplastic syndrome. Br. J. Haematol 117, 119-126 (2002). [PubMed: 11918541]

36. Fenaux P et al. Luspatercept in Patients with Lower-Risk Myelodysplastic Syndromes. N. Engl. J. Med 382, 140-151 (2020). [PubMed: 31914241]

37. Suragani RN et al. Transforming growth factor-beta superfamily ligand trap ACE-536 corrects anemia by promoting late-stage erythropoiesis. Nat. Med 20, 408-414 (2014). [PubMed: 24658078]

38. Mattapallil MJ et al. Interleukin 22 ameliorates neuropathology and protects from central nervous system autoimmunity. J. Autoimmun 102, 65-76 (2019). [PubMed: 31080013]

39. Smith CL et al. IL-22 regulates iron availability in vivo through the induction of hepcidin. J. Immunol 191, 1845-1855 (2013). [PubMed: 23836059]

40. Sakamoto K et al. IL-22 Controls Iron-Dependent Nutritional Immunity Against Systemic Bacterial Infections. Sci Immunol 2, (2017).

41. Pietras EM et al. Chronic interleukin-1 exposure drives haematopoietic stem cells towards precocious myeloid differentiation at the expense of self-renewal. Nat. Cell Biol 18, 607-618 (2016). [PubMed: 27111842]

42. Yamashita M \& Passegue E TNF-alpha Coordinates Hematopoietic Stem Cell Survival and Myeloid Regeneration. Cell Stem Cell 25, 357-372 e357 (2019). [PubMed: 31230859]

43. Zhang TY et al. IL-6 blockade reverses bone marrow failure induced by human acute myeloid leukemia. Sci. Transl. Med 12, (2020).

44. Cai T et al. Increased expression of IL-22 is associated with disease activity in Behcet's disease. PLoS One 8, e59009 (2013). [PubMed: 23527071]

45. Yamamoto-Furusho JK et al. Colonic epithelial upregulation of interleukin 22 (IL-22) in patients with ulcerative colitis. Inflamm. Bowel Dis 16, 1823 (2010). [PubMed: 20222141]

46. Lee SJ et al. Certain Autoimmune Manifestations Are Associated With Distinctive Karyotypes and Outcomes in Patients With Myelodysplastic Syndrome: A Retrospective Cohort Study. Medicine (Baltimore) 95, e3091 (2016). [PubMed: 27043672]

47. Fozza C, La Nasa G \& Caocci G The Yin and Yang of myelodysplastic syndromes and autoimmunity: The paradox of autoimmune disorders responding to therapies specific for MDS. Crit. Rev. Oncol. Hematol 142, 51-57 (2019). [PubMed: 31376677]

48. Wolach O \& Stone R Autoimmunity and Inflammation in Myelodysplastic Syndromes. Acta Haematol. 136, 108-117 (2016). [PubMed: 27337745]

49. Schnatter AR, Glass DC, Tang G, Irons RD \& Rushton L Myelodysplastic syndrome and benzene exposure among petroleum workers: an international pooled analysis. J. Natl. Cancer Inst 104, 1724-1737 (2012). [PubMed: 23111193]

50. Boitano AE et al. Aryl hydrocarbon receptor antagonists promote the expansion of human hematopoietic stem cells. Science 329, 1345-1348 (2010). [PubMed: 20688981] 


\section{References (Methods Only):}

51. Skarnes WC et al. A conditional knockout resource for the genome-wide study of mouse gene function. Nature 474, 337-342 (2011). [PubMed: 21677750]

52. Farley FW, Soriano P, Steffen LS \& Dymecki SM Widespread recombinase expression using FLPeR (flipper) mice. Genesis 28, 106-110 (2000). [PubMed: 11105051]

53. Heinrich AC, Pelanda R \& Klingmuller U A mouse model for visualization and conditional mutations in the erythroid lineage. Blood 104, 659-666 (2004). [PubMed: 15090451]

54. Savage AK, Liang HE \& Locksley RM The Development of Steady-State Activation Hubs between Adult LTi ILC3s and Primed Macrophages in Small Intestine. J. Immunol 199, 1912 1922 (2017). [PubMed: 28747343]

55. Schneider RK et al. Rps 14 haploinsufficiency causes a block in erythroid differentiation mediated by S100A8 and S100A9. Nat. Med 22, 288-297 (2016). [PubMed: 26878232]

56. Pronk CJ et al. Elucidation of the phenotypic, functional, and molecular topography of a myeloerythroid progenitor cell hierarchy. Cell Stem Cell 1, 428-442 (2007). [PubMed: 18371379]

57. Shuga J, Zhang J, Samson LD, Lodish HF \& Griffith LG In vitro erythropoiesis from bone marrow-derived progenitors provides a physiological assay for toxic and mutagenic compounds. Proc. Natl. Acad. Sci. U. S. A 104, 8737-8742 (2007). [PubMed: 17502613]

58. Myers SA et al. Streamlined Protocol for Deep Proteomic Profiling of FAC-sorted Cells and Its Application to Freshly Isolated Murine Immune Cells. Mol. Cell. Proteomics 18, 995-1009 (2019). [PubMed: 30792265]

59. Rappsilber J, Ishihama Y \& Mann M Stop and go extraction tips for matrix-assisted laser desorption/ionization, nanoelectrospray, and LC/MS sample pretreatment in proteomics. Anal. Chem 75, 663-670 (2003). [PubMed: 12585499]

60. Shalek AK et al. Single-cell transcriptomics reveals bimodality in expression and splicing in immune cells. Nature 498, 236-240 (2013). [PubMed: 23685454]

61. Picelli $S$ et al. Smart-seq2 for sensitive full-length transcriptome profiling in single cells. Nat Methods 10, 1096-1098 (2013). [PubMed: 24056875]

62. Langmead B, Trapnell C, Pop M \& Salzberg SL Ultrafast and memory-efficient alignment of short DNA sequences to the human genome. Genome Biol. 10, R25 (2009). [PubMed: 19261174]

63. Li B \& Dewey CN RSEM: accurate transcript quantification from RNA-Seq data with or without a reference genome. BMC Bioinformatics 12, 323 (2011). [PubMed: 21816040]

64. Subramanian A et al. Gene set enrichment analysis: a knowledge-based approach for interpreting genome-wide expression profiles. Proc. Natl. Acad. Sci. U. S. A 102, 15545-15550 (2005). [PubMed: 16199517]

65. Dudakov JA, Hanash AM \& van den Brink MR Interleukin-22: immunobiology and pathology. Annu. Rev. Immunol 33, 747-785 (2015). [PubMed: 25706098]

66. Liberzon A et al. Molecular signatures database (MSigDB) 3.0. Bioinformatics 27, 1739-1740 (2011). [PubMed: 21546393]

67. Nikolsky Y, Ekins S, Nikolskaya T \& Bugrim A A novel method for generation of signature networks as biomarkers from complex high throughput data. Toxicol. Lett 158, 20-29 (2005). [PubMed: 15871913]

68. Pellagatti A et al. Deregulated gene expression pathways in myelodysplastic syndrome hematopoietic stem cells. Leukemia 24, 756-764 (2010). [PubMed: 20220779]

69. Barrett T et al. NCBI GEO: archive for functional genomics data sets--update. Nucleic Acids Res. 41, D991-995 (2013). [PubMed: 23193258]

70. Edgar R, Domrachev M \& Lash AE Gene Expression Omnibus: NCBI gene expression and hybridization array data repository. Nucleic Acids Res. 30, 207-210 (2002). [PubMed: 11752295] 


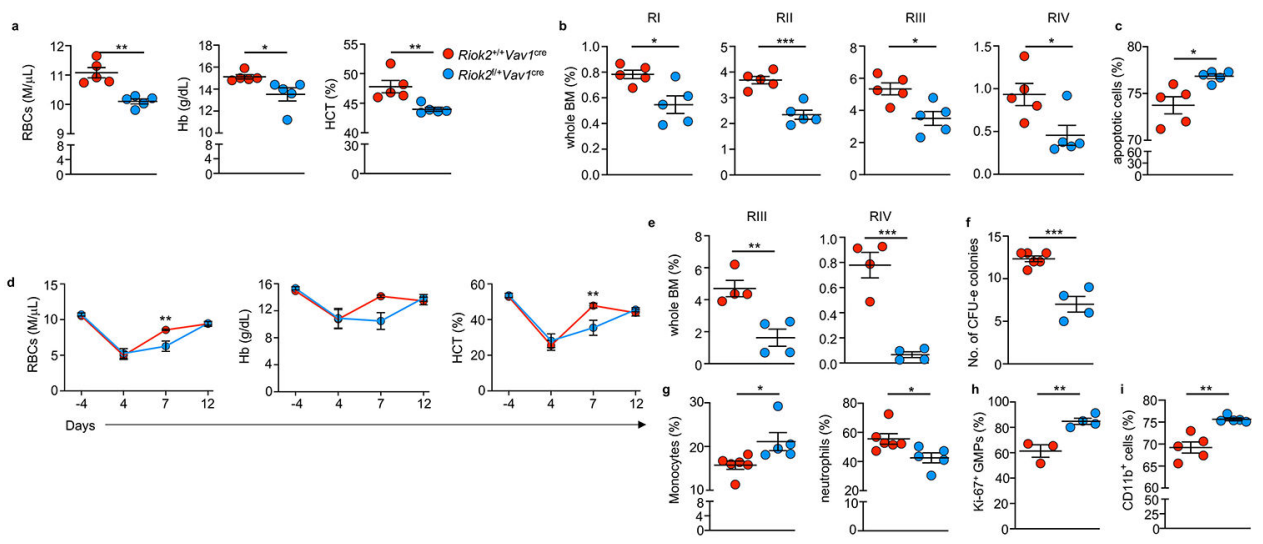

Figure 1. Riok2 haploinsufficient $\left(\operatorname{Riok}^{\mathrm{f} /+} \operatorname{Vav1}^{\mathrm{cre}}\right)$ mice display anemia and myeloproliferation. (a) Peripheral blood (PB) RBC numbers, hemoglobin (Hb), and hematocrit (HCT) in Riok $2^{\mathrm{f} /+}$ Vav $^{\text {cre }}$ mice in comparison to Riok $^{+/+}$Vav $^{\text {cre }}$ controls (n=5/group). (b) Frequency of erythroid progenitor/precursor populations among viable bone marrow (BM) cells in Riok2 $2^{\mathrm{f} /+}$ Vav $^{\text {cre }}$ mice and Riok2 $2^{+/+} \operatorname{Vav}^{\text {cre }}$ controls (n=5/group). (c) Frequency of apoptotic erythroid precursors among viable BM cells in Riok $^{\mathrm{f} /+} \mathrm{VaV}^{\mathrm{cre}}$ mice and $\mathrm{Riok}^{+/+} \mathrm{VaV}^{\mathrm{cre}}$ controls (n=5/group). (d) PB RBC numbers, Hb, and HCT in Riok ${ }^{\mathrm{f} /+}$ Vav $^{\text {cre }}$ mice and Riok $^{+/+}$Vav $^{\text {cre }}$ controls undergoing phenylhydrazine ( $\mathrm{PhZ}$ )-induced stress erythropoiesis (n=7/group). (e) Frequency of RIII and RIV erythroid precursor populations among viable BM cells in Riok $^{\mathrm{f} /+} \mathrm{VaV}^{\mathrm{cre}}$ mice and Riok $2^{+/+} \mathrm{Vav}^{\mathrm{cre}}$ controls day 6 after PhZ treatment ( $\mathrm{n}=4 /$ group). (f) Number of CFU-e colonies in Epo-containing MethoCult assay using Lin ${ }^{-}$c-kit ${ }^{+} \mathrm{CD} 71^{+}$cells from Riok $^{\mathrm{f} /+} \operatorname{Vav}^{\text {cre }}$ mice $(\mathrm{n}=4)$ in comparison to Riok $^{+/+}$Vav $^{\text {cre }}$ controls $(\mathrm{n}=6)$. (g) Percentage of monocytes $\left(\mathrm{CD} 11 \mathrm{~b}^{+} \mathrm{Ly}_{6 \mathrm{G}^{-}} \mathrm{Ly}^{\mathrm{C}} \mathrm{C}^{\mathrm{hi}}\right)$ and neutrophils $\left(\mathrm{CD} 11 \mathrm{~b}^{+} \mathrm{Ly}_{6 \mathrm{G}}^{+}\right)$in the PB of Riok $^{\mathrm{f} /+} \operatorname{Vav}^{\mathrm{Cre}}$ mice $(\mathrm{n}=6)$ in comparison to Riok $^{+/+}$Vav $^{\text {cre }}$ controls ( $\mathrm{n}=5)$. (h) Percentage of $\mathrm{Ki}-67^{+}$granulocyte-macrophage progenitors (GMPs) in the BM of Riok $2^{\mathrm{f} /+} \operatorname{Vav}^{\mathrm{cre}}$ mice $(\mathrm{n}=3)$ and Riok $2^{+/+} \operatorname{Vav}^{\text {cre }}$ controls $(\mathrm{n}=4)$. (i) Percentage of

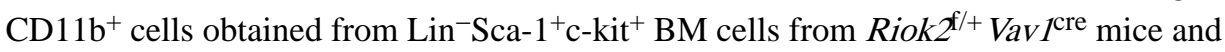
Riok $2^{+/+}$Vav $^{\text {cre }}$ controls cultured in MethoCult for 7 days (n=5/group). Unpaired two-tailed $t$-test (a to c, e to i) and 1-way ANOVA with Tukey's correction for multiple comparisons (d) used to calculate statistical significance. * $\mathrm{p}<0.05$, ** $\mathrm{p}<0.01$, *** $\mathrm{p}<0.001$. Data are shown as mean \pm s.e.m and are representative of two $(c, d, f-h)$ or three $(a, b, e, i)$ independent experiments. 


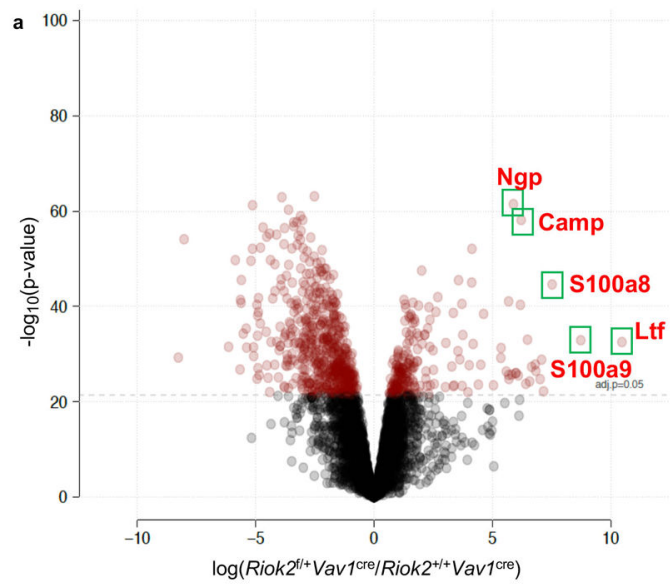

\begin{tabular}{|c|c|c|c|c|}
\hline & \multicolumn{3}{|c|}{$\begin{array}{c}\text { Riok2 } \\
\text { haploinsufficiency }\end{array}$} & \multicolumn{2}{|c|}{$\begin{array}{c}\text { Rps14 } \\
\text { hap ploinsufficiency }\end{array}$} \\
\hline Proteins & Adj. p-val & Log Fold Change & Adj. p-val & Log Fold Change \\
\hline Cathelicidin (CAMP) & 0.002 & 12.03 & 0.003 & 1.37 \\
\hline NGP & 0.002 & 8.73 & 0.003 & 1.35 \\
\hline S100A9 & 0.002 & 8.57 & 0.002 & 1.45 \\
\hline Lactotransferrin (LTF) & 0.001 & 7.38 & 0.005 & 1.45 \\
\hline S100A8 & 0.003 & 6.29 & 0.001 & 2.05 \\
\hline
\end{tabular}
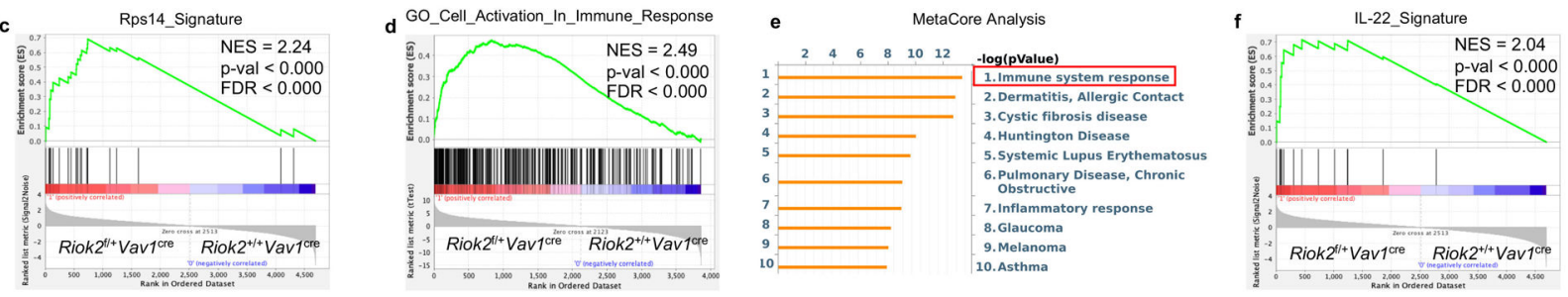

Figure 2. Quantitative proteomics of Riok2 haploinsufficient erythroid precursors reveals immune activation signatures.

(a) Proteomic analysis of changes in protein expression in erythroid progenitors from Riok2 haploinsufficient mice and $\mathrm{Vavl}^{\mathrm{cre}}$ controls. $\mathrm{n}=4-5 \mathrm{mice} / \mathrm{group}$. (b) Comparison of upregulated proteins with their respective p-values and log fold-change values in erythroid precursors from Riok 2 haploinsufficient mice and Rps 14 haploinsufficient mice with their respective controls. (c to d, f) GSEA performed on proteomics data shown in (a) to reveal similarity with Rps14 haploinsufficient data (c), activation of immune response (d) and enrichment of IL-22 signature genes (f). NES = Normalized enrichment score, FDR = False discovery rate. (e) MetaCore analysis of the Riok2 proteomics dataset shown in (a). Two sample moderated $t$-test with multiple hypothesis corrections used to calculate the statistical significance in (b). 

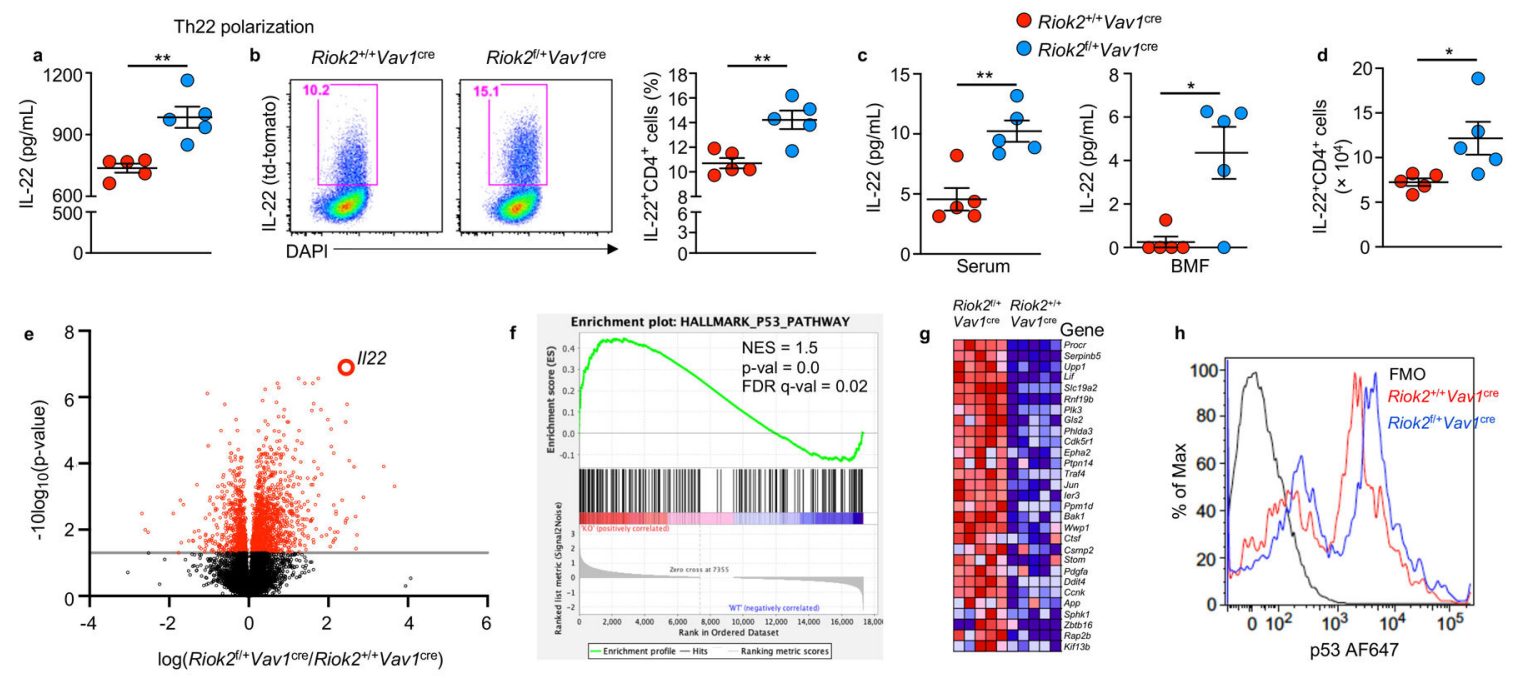

i

j
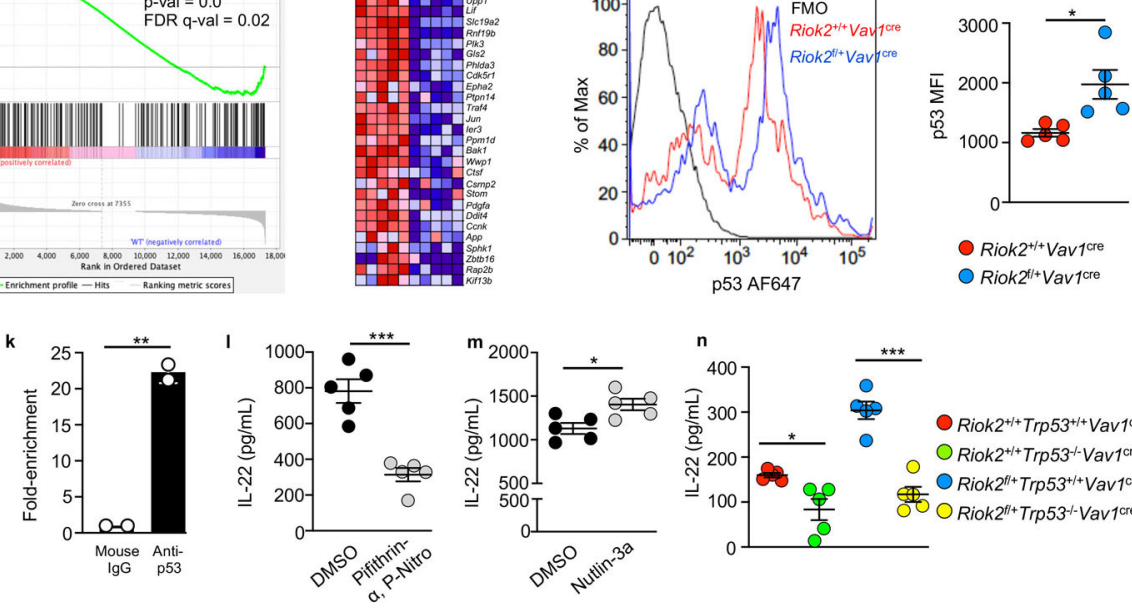

Figure 3. Riok2 haploinsufficiency-driven p53 upregulation drives increased IL-22.

(a) Secreted IL-22 and (b) Percentage of IL-22 ${ }^{+} \mathrm{CD}^{+} \mathrm{T}$ cells from in vitro polarized $\mathrm{T}_{\mathrm{H}} 22$ cells from Riok $2^{f+} \operatorname{VaV}{ }^{\text {cre }}$ mice and Riok $2^{+/+} \operatorname{VaV}^{\text {cre }}$ controls (n=5/group). (c) IL-22 levels in the serum (left) and bone marrow fluid (BMF) (right) in $R i o k 2^{f+} \operatorname{Vav}^{\text {cre }}$ mice and Riok $2^{+/+} \operatorname{Vav}^{\text {cre }}$ controls (n=5/group). (d) Number of IL-22 ${ }^{+} \mathrm{CD} 4^{+}$cells in the spleens of Riok $2^{\mathrm{f} /+} \operatorname{Vav}^{\text {cre }}$ mice and Riok ${ }^{+/+} \operatorname{Vav}^{\text {cre }}$ controls (n=5/group). (e) Volcano plot showing transcriptomic changes in purified IL-22 $2^{+}$cells from Riok $2^{f /+} \operatorname{Vav}^{1 \text { re }}$ mice in comparison to

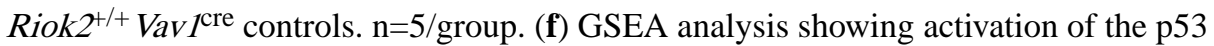
pathway in IL-22+ cells from Riok $2^{f t+} \operatorname{Vav}^{\text {cre }}$ mice in comparison to Riok $^{+/+} \operatorname{Vav}^{\text {cre }}$ controls. (g) Snapshot of differentially expressed genes in the p53 pathway shown in (F) in

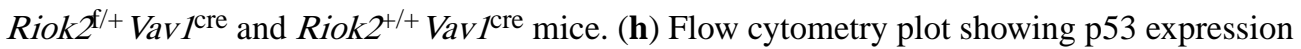

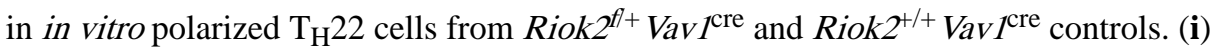
Graphical representation of data shown in $(\mathrm{H}) . \mathrm{n}=5$ /group. (j) Predicted $\mathrm{p} 53$ binding site in the II22 promoter region. (k) Chromatin immunoprecipitation showing p53 occupancy at the III2 promoter in T cells. $\mathrm{n}=2$ independent experiments. (l) Secreted IL-22 from wt $\mathrm{T}_{\mathrm{H}} 22$ cells cultured in the presence or absence of p53 inhibitor, pifithrin-a, p-nitro $(1 \mu \mathrm{M}) . n=5$ mice/group. (m) Secreted IL-22 from WT $\mathrm{T}_{\mathrm{H}} 22$ cells cultured in the presence or absence of p53 activator, Nutlin-3 (100 nM). $\mathrm{n}=4$ mice/group. (n) Secreted IL-22 from in vitro polarized $\mathrm{T}_{\mathrm{H}} 22$ cells from the indicated strains. $\mathrm{n}=5$ /group. Unpaired two-tailed $t$-test (a to d, $\mathrm{i}, \mathrm{k}-\mathrm{m}$ ) and 1-way ANOVA with Tukey's correction for multiple comparison (n) used to calculate statistical significance. ${ }^{*} \mathrm{p}<0.05, * * \mathrm{p}<0.01$, $* * * \mathrm{p}<0.001$. Data are shown as mean \pm s.e.m and are representative of two $(c-d, h, i, k-n)$ or three $(a, b)$ independent experiments. Data in $(\mathrm{k})$ is represented as mean \pm s.d. and is pooled from two independent experiments. 

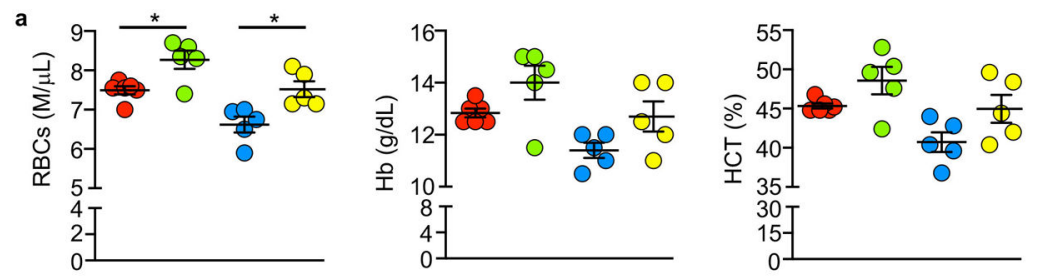

O Riok $2^{+++/ 1 / 22^{+++} \operatorname{Vav} 1 \text { cre/+ }}$

O Riok $2^{+/+} / 1 / 22^{+/-}$Vav1 crel+ $^{\text {O }}$

O Riok $2^{f+} / 1 / 22^{+/+}$Vav1 crel+ $^{+}$

O Riok $2^{f+/} / 122^{+1-V a v 1 \text { crel+ }}$
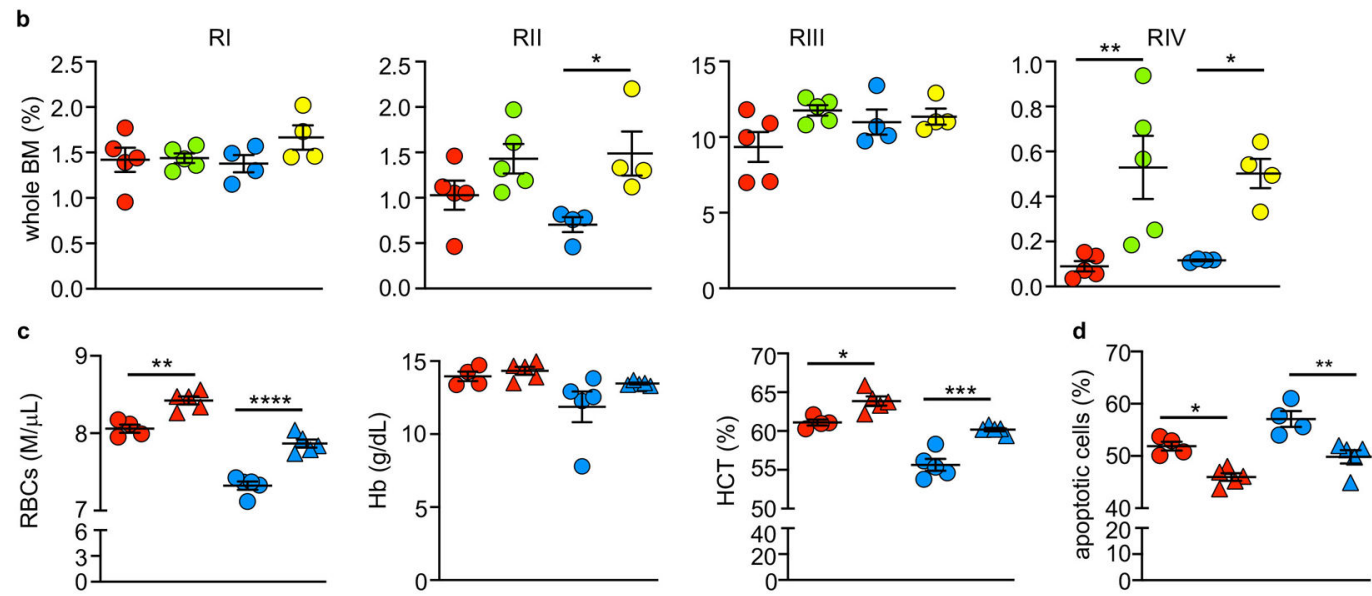

Riok ${ }^{+++}$Vav1 ${ }^{\text {crel+ }+}$ Isotype

$\triangle$ Riok $2^{+/+}$Vav1 ${ }^{\text {crel+ }}+$ anti-IL-22

Riok2 $2^{\mathrm{f} /+}$ Vav1 ${ }^{\mathrm{cre} /+}+$ Isotype

$\triangle$ Riok $2^{\mathrm{f} /+}$ Vav $1^{\text {cre } /+}+$ anti-IL-22

Figure 4. IL-22 neutralization alleviates stress-induced anemia in Riok2 sufficient and haploinsufficient mice.

(a) PB RBC numbers, $\mathrm{Hb}$, and HCT in the indicated strains undergoing PhZ-induced stress erythropoiesis. n=6,5,5, and 5 mice for Riok $^{+/+} I I 22^{+/+} \mathrm{VaV}^{\mathrm{cre}}, \mathrm{Riok}^{+/+} \mathrm{II} 22^{+/-} \mathrm{VaV}^{\mathrm{cre}}$, Riok $2^{\mathrm{f} /+} I I 22^{+/+} \mathrm{VaV}^{\mathrm{cre}}, \mathrm{Riok}^{\mathrm{f} /+} I I 22^{+/-} \mathrm{VaV}^{\mathrm{cre}}$, respectively. (b) Frequency of erythroid progenitor/precursor populations among viable BM cells in the indicated strains undergoing PhZ-induced stress erythropoiesis ( $\mathrm{n}=4-5 /$ group). (c) PB RBC numbers, Hb, and HCT in Riok $2^{f t+}$ Vav $^{\text {cre }}$ mice and Riok $2^{+/+}$Vav $^{\text {cre }}$ controls undergoing PhZ-induced stress erythropoiesis treated with either an isotype control or anti-IL-22 antibody (n=4-5/group). (d) Frequency of apoptotic erythroid precursors among viable BM cells in Riok $2^{f++} \mathrm{Vav} \mathrm{I}^{\mathrm{cre}}$ mice and Riok $^{+/+}$Vav $^{\text {cre }}$ controls undergoing PhZ-induced stress erythropoiesis treated with either an isotype control or anti-IL-22 antibody. $\mathrm{n}=4,5,4$, and 5 mice for isotype-treated Riok $^{+/+}$Vav $^{\text {cre }}$, anti-IL-22-treated Riok $2^{+/+}$Vav $^{\text {cre }}$, isotype-treated Riok $2^{\mathrm{f} /+}$ Vav $^{\text {cre }}$, and anti-IL-22-treated $\operatorname{Riok}^{\mathrm{f} /+} \mathrm{Vav}^{\mathrm{cre}}$ mice, respectively. 1-way ANOVA with Tukey's correction for multiple comparison (a to d) used to calculate statistical significance. * p < $0.05, * * \mathrm{p}<0.01, * * * \mathrm{p}<0.001, * * * * \mathrm{p}<0.0001$. Data are shown as mean \pm s.e.m and are representative of two $(c, d)$ or three $(a, b)$ independent experiments. 

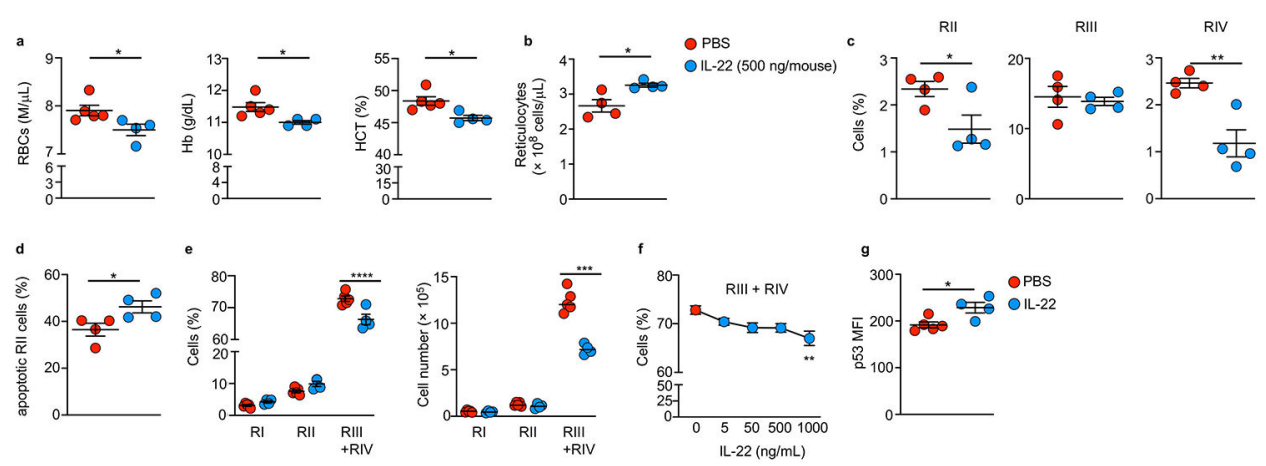

Figure 5. Recombinant IL-22 exacerbates PhZ-induced anemia in wt mice.

(a) PB RBC numbers, Hb, and HCT in wt C57BL/6J mice administered PBS $(\mathrm{n}=5)$ or rIL-22 ( $n=4)$ and subsequently treated with PhZ. $n=4-5$ mice/group. (b) PB reticulocytes in mice treated as in (a). $n=4$ mice/group. (c) Percentage of RII-RIV erythroid precursors in the BM of PBS- or rIL-22-treated C57BL/6J mice 7 days after $\mathrm{PhZ}$ administration. $\mathrm{n}=4$ mice/ group. (d) Percentage of apoptotic RII erythroid precursors in mice treated as in $(C) . n=4$ mice/group. (e) Effect of recombinant IL-22 $(500 \mathrm{ng} / \mathrm{mL})$ on the frequency (left) and cell number (right) in an in vitro erythropoiesis assay and (f) dose dependent effect of recombinant IL-22. n=5 and 4 for PBS and IL-22 groups, respectively. (g) p53 expression in in in vitro erythropoiesis culture treated with rIL-22 or PBS. $\mathrm{n}=5$ and 4 mice for PBS and IL-22 groups, respectively. Data are shown as mean \pm s.e.m and are representative of three $(\mathrm{a}, \mathrm{b})$ or two ( $\mathrm{c}$ to $\mathrm{g}$ ) independent experiments. Unpaired two-tailed $t$-test (A to $\mathrm{D}, \mathrm{G}$ ), multiple unpaired two-tailed $t$-tests with Holm-Sidak method (e) and 1-way ANOVA with Tukey's correction for multiple comparisons (f) used to calculate statistical significance. ${ }^{*} \mathrm{p}$ $<0.05, * * \mathrm{p}<0.01, * * * \mathrm{p}<0.001, * * * * \mathrm{p}<0.0001$. 

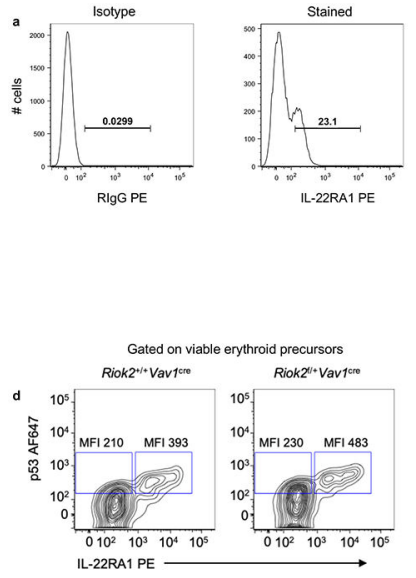
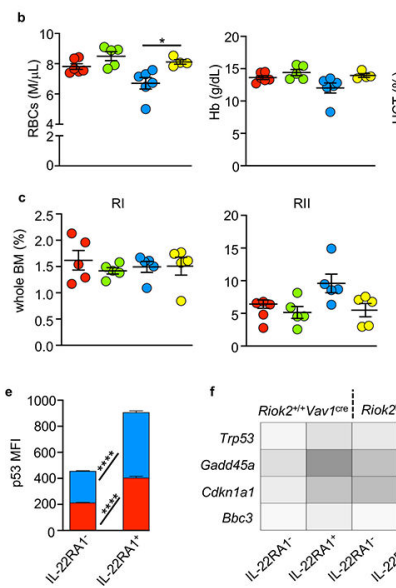

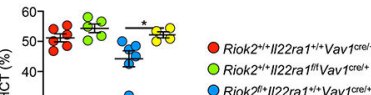

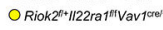

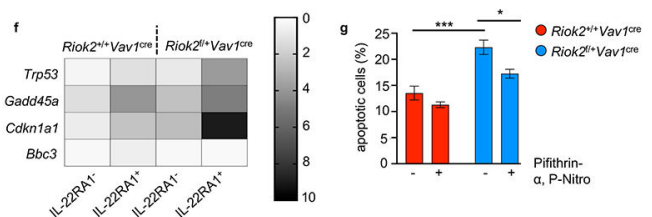

Figure 6. Genetic deletion of Il22ral alleviates anemia in Riok2 haploinsufficient mice. (a) IL-22RA1 expression on BM erythroid precursors in wild-type (WT) mice assessed by flow cytometry using antibody from Novus Biologicals targeting the extracellular domain of IL-22RA1. (b) PB RBC numbers, Hb, and HCT in the indicated strains undergoing PhZinduced stress erythropoiesis. $\mathrm{n}=6,5,6$, and 4 mice for $\mathrm{Riok}^{+/+} I 122 \mathrm{rla}^{+/+} \mathrm{Vav}^{\mathrm{cre}}$,

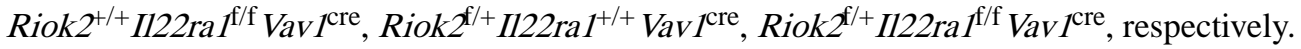
(c) Frequency of erythroid progenitor/ precursor populations among viable BM cells in the indicated strains undergoing PhZ-induced stress erythropoiesis ( $\mathrm{n}=5 /$ group). (d) Flow cytometry plots showing p53 expression in IL-22RA1 ${ }^{+}$and IL-22RA1- erythroid precursors in Riok $^{\mathrm{f} /+}$ Vav $^{\text {cre }}$ mice and Riok2 ${ }^{+/+}$Vav $^{\text {cre }}$ controls. n=5/group. (e) Graphical representation of data shown in (D). (f) Gene expression of Trp53 (p53) and listed p53 target genes in IL-22RA1 ${ }^{+}$and IL-22RA1- erythroid precursors from Riok $2^{\mathrm{f} /+} \mathrm{Vav}^{\mathrm{cre}}$ and Riok $2^{+/+}$Vav $^{\text {cre }}$ mice assessed by qRT-PCR. n=3/group. (g) Frequency of apoptotic cells (assessed by flow cytometry) with $(n=4)$ or without $(n=5)$ p53 inhibitor, pifithrin-a, p-nitro $(1 \mu \mathrm{M})$, in an in vitro erythropoiesis assay using Lin $^{-}$BM cells from Riok $2^{\mathrm{f} /+}$ Vav $^{\text {cre }}$ and Riok $2^{+/+}$Vav $^{\text {cre }}$ mice. 2-way ANOVA with Tukey's correction for multiple comparisons (e, g) and 1-way ANOVA with Tukey's correction for multiple comparison (b, c) used to calculate statistical significance. $* \mathrm{p}<0.05, * * \mathrm{p}<0.01, * * * \mathrm{p}<0.001, * * * * \mathrm{p}<0.0001$. Data are shown as mean \pm s.e.m and are representative of two (D-G) or three (a to c) independent experiments. 

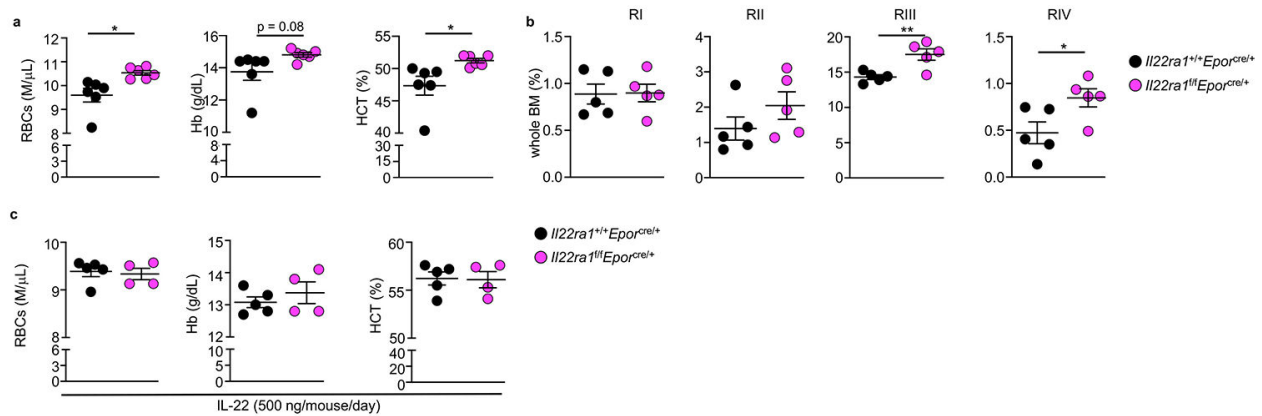

- $1 / 22$ ra $1^{1 / 4}$ Eporvelt

Figure 7. Erythroid-specific deletion of IL-22RA1 alleviates stress-induced anemia.

(a) PB RBC numbers, $\mathrm{Hb}$, and HCT in the indicated strains undergoing PhZ-induced stress erythropoiesis ( $\mathrm{n}=6 /$ group). (b) Frequency of erythroid progenitor/precursor populations

among viable BM cells in the indicated strains undergoing PhZ-induced stress erythropoiesis (n=5/group). (c) PB RBC numbers, Hb, and HCT in $\mathrm{Il}_{2} 2 \mathrm{raI}^{+/+} \mathrm{Epor}^{\text {cre }}(\mathrm{n}=5)$ and II22ra $I^{\mathrm{f} / \mathrm{f}} \mathrm{Epor}^{\text {cre }}(\mathrm{n}=4)$ mice administered rIL-22 and subsequently treated with PhZ. n=4-5 mice/group. Unpaired two-tailed $t$-test (a-c) used to calculate statistical significance. $* \mathrm{p}<$ $0.05, * * * \mathrm{p}<0.001$. Data are shown as mean \pm s.e.m and are representative of two (a-c) independent experiments. 


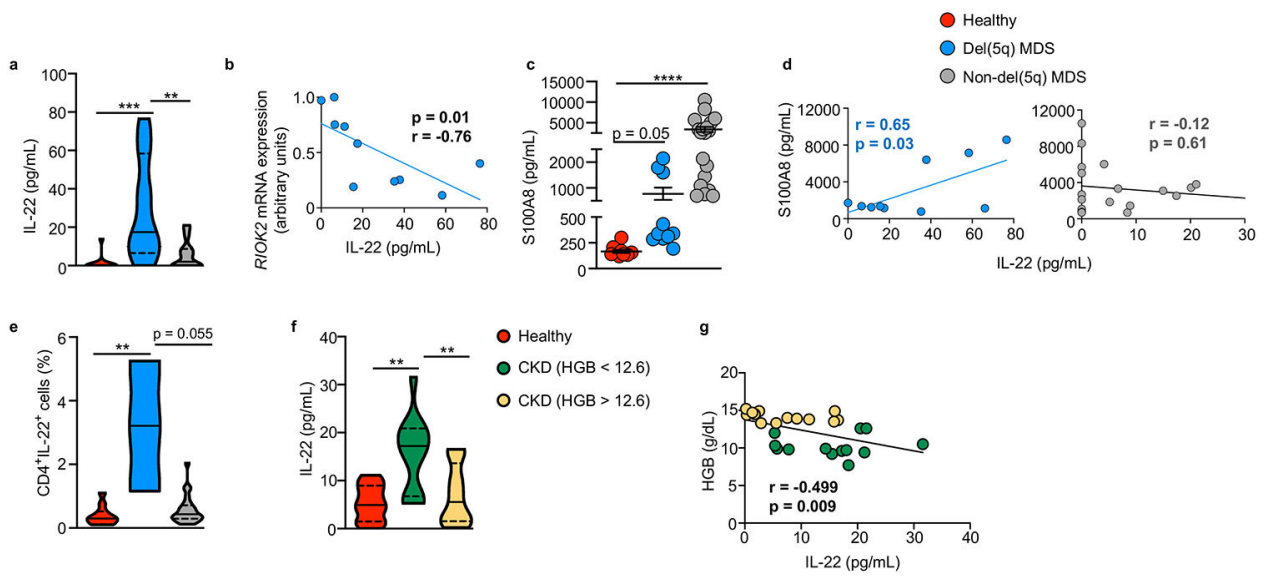

Figure 8. MDS patients exhibit increased IL-22 levels and IL-22 associated signature. (a) IL-22 concentration in the BM fluid of healthy controls $(n=12), \operatorname{del}(5 q) \operatorname{MDS}(n=11)$, and non-del(5q) MDS ( $\mathrm{n}=22)$ patients. (b) Correlation between RIOK2 mRNA and BM IL-22 concentration in the $\operatorname{del}(5 \mathrm{q})$ cohort shown in $(\mathrm{a}), \mathrm{n}=10$. (c) $\mathrm{S} 100 \mathrm{~A} 8$ concentration in the samples shown in (a). $n=11,10$, and 19 for healthy, $\operatorname{del}(5 \mathrm{q}) \mathrm{MDS}$, and non-del(5q) MDS, respectively. (d) Correlation between IL-22 concentration and S100A8 concentration in BM fluid of $\operatorname{del}(5 \mathrm{q})$ (left, $\mathrm{n}=10$ ) and non-del(5q) (right, $\mathrm{n}=19)$ samples. (e) Frequency of IL-22 producing CD4 ${ }^{+}$T cells in the PB of healthy controls $(n=11), \operatorname{del}(5 q)(n=3)$ and non$\operatorname{del}(5 q)(n=24)$ MDS patients. (f) Plasma IL-22 concentration in healthy subjects $(n=10)$ and chronic kidney disease $(\mathrm{CKD})$ patients with $(\mathrm{n}=13)$ or without $(\mathrm{n}=13)$ secondary anemia. $(\mathbf{g})$ Correlation between plasma IL-22 concentration and hemoglobin (HGB) in CKD patients with $(n=13)$ or without $(n=13)$ anemia. Kruskal-Wallis test with Dunn's correction for multiple comparisons (a to c, e), 1-way ANOVA with Tukey's correction for multiple comparisons (f) used to calculate statistical significance. Pearson correlation co-efficient (b, $\mathrm{d}, \mathrm{g}$ ), used to calculate statistical significance and correlation coefficient. $* * \mathrm{p}<0.01$, *** $\mathrm{p}$ $<0.001$, $* * * * \mathrm{p}<0.0001$. Data are shown as mean \pm s.e.m (c). Solid lines represent median and dashed lines represent quartiles (a, e, f). 